\title{
O Manifesto dos \\ Tratados de Arquitetura em Vila Rica Setentista \\ O pórtico toscano do Palácio dos Governadores de José Fernandes Pinto Alpoim
}

\author{
Marcos Tognon*
}

\begin{abstract}
Resumo Projetado em 1740 pelo engenheiro militar português José Fernandes PInto Alpoim, o Palácio dos Governadores, na então cidade de Vila Rica, hoje Ouro Preto, representou a definitiva instauração do poder de Dom João $V$ na prometida terra do ouro que, após muitas insubordinações sociais desde os primeiros anos de 1700, seria intensamente urbanizada, civilizada, monumentalizada pelo seu governador, Gomes Freire de Andrade, efetivando assim a sua subordinação e deferência à monarquia e aos valores lusitanos. Palácio fortaleza que foi implantado entre as duas paróquias mais densamente habitadas da vila, e cujo pórtico de entrada trazia, em sua composição formal e proporcional, o mais límpido manifesto da linguagem arquitetônica cultuada nos tratados de Arquitetura desde o século XVI.
\end{abstract}

Palavras-chave: história da arquitetura militar em Minas Gerais, linguagem arquitetônica, tradição clássica.

\section{El manifiesto de los Tratados de Arqui- tectura en la Vila Rica del siglo XVIII: el pór- tico toscano del Palacio de los Gobernadores de José Fernandes Pinto Alpoim}

Resumen Diseñado en 1740 por el ingeniero militar portugués José Fernandes PInto Alpoim, el Palacio de los Gobernadores, en la entonces ciudad de Vila Rica, hoy Ouro Preto, representó el establecimiento definitivo del poder de Dom João V en la prometida tierra de oro que, después de muchas insubordinaciones sociales desde Los primeros años de 1700, sería intensamente urbanizado, civilizado, monumentalizado por su gobernador, Gomes Freire de Andrade, lo que afectaría su subordinación y deferencia a la monarquía y los valores portugueses. Palacio fortaleza que se implantó entre las dos parroquias más densamente pobladas de la aldea, y cuyo pórtico de entrada trajo, en su composición formal y proporcional, la manifestación más clara del lenguaje arquitectónico adorado en los Tratados de Arquitectura desde el siglo XVI.

Palabras clave: historia de la arquitectura militar en Minas Gerais, lenguaje arquitectónico, tradición clásica.

\section{The manifest of the Treaties of Architecture in 18th century Vila Rica: the Tuscan portico of the Palace of the Governors of José Fernandes Pinto Alpoim}

\begin{abstract}
Designed in 1740 by Portuguese military engineer José Fernandes PInto Alpoim, the Governors' Palace, in the then city of Vila Rica, today Ouro Preto, represented the definitive establishment of the power of Dom João $\mathrm{V}$ in the promised land of gold that, after many social insubordinations since the first years of 1700, it would be intensely urbanized, civilized, monumentalized by its governor, Gomes Freire de Andrade, thus effecting its subordination and deference to the monarchy and Portuguese values. Fortress palace that was implanted between the two most densely populated parishes of the village, and whose entrance porch brought, in its formal and proportional composition, the clearest manifest of the architectural language worshiped in the Treaties of Architecture since the 16th century.

Keywords: history of military architecture in Minas Gerais, architectural language, classical tradition.
\end{abstract}


$-\mathbf{Q}$

uem vislumbra a grande mole branca na elevação setentrional da praça ouro-pretana em homenagem a Tiradentes certamente fixa a sua atenção, pela escala e pela massa murária oferecida, no arranjo topográfico inusitado de uma rampa que ascende a um terrapleno elevado, rampa contraposta à via que declina, à direita, para a saída rumo a Mariana. [Figura 1]

Esse conjunto de rampa, terrapleno, edificações assobradas ao fundo com um inapropriado paisagismo frontal nos dão a nítida sensação de que, em síntese, nosso monumento, o atual Museu de Ciências da Universidade Federal de Ouro Preto, não mais se ajusta ao requadro perspéctico da praça capitaneada por Tiradentes; e, se não fossem as guaritas circulares que se repetem em altimetrias distintas, seria mais improvável ainda que reconhecêssemos a primeira fortaleza-casa dos governadores da província mineira emancipada em meados dos Setecentos. Assim, o contexto construtivo atual, irregular e desconfortável do Palácio dos Governadores minimiza gravemente o que seria a mais vetusta e qualificada manifestação da Arquitetura em Vila Rica: o pórtico toscano de entrada da antiga fortificação executado em cantaria pelo mestre Caetano da Silva Ruivo, sob risco do engenheiro militar José Fernandes Pinto Alpoim a partir de 1740. [Figura 2]

Esta comunicação, portanto, se concentra no reconhecimento pleno de que o pórtico toscano desenhado por Alpoim na elevação frontal do então Palácio dos Governadores não só prima pelas designações formais dos tratados de Arquitetura Militar, mas também seria a primeira manufatura lítica erudita e rigorosa de matriz clássica na vila florescente sob o Itacolomi, seja na plástica, na composição e na proporção, iniciando uma nova era técnico-visual pela arte da cantaria em Ouro Preto; e, cujas repercussões, no futuro, serão consagradas pelas capelas e matrizes, novas ou reformadas, na segunda metade do século XVIII ${ }^{1}$.

A fortuna crítica do Palácio dos Governadores e sua construção é limitada a poucas referências, mas densas, graças a dois estudiosos exemplares, respectivamente, do engenheiro Francisco Antônio Lopes e o arquiteto Ivo Porto de Meneses, que se interessaram por esse assunto em um arco temporal de 50 anos 2 .

Ambos se baseiam na publicação dos documentos originais de construção do Palácio dos Governadores desde a primeira metade do século XVIII na Revista do Arquivo Público Mineiro ${ }^{3}$ : Lopes se destaca pela pormenorizada descrição de todas as etapas de construção dessa casa fortaleza, desde as decisões políticas e estratégicas do governador Gomes de Freire de Andrade, o primeiro Conde de Bobadela, até a o cultivo

* Marcos Tognon é Arquiteto e Urbanista, professor do Departamento de História do Instituto de Filosofia e Ciências Humanas da Unicamp, ORCID <https://orcid. org/0000-0001-7962-0031>. do "Jardim Pagão" na área posterior do conjunto 4; Meneses empreende a História do Palácio guiado também pela cronologia das iniciativas que almejavam uma casa estável para os governadores de Minas entre 1720 e 1740, porém traz informações visuais muito eloquentes não só da grande mole da Praça Tiradentes na sua vista aérea de 1939, mas, também, da precedente sede da Encardideira, na região de Antônio 
O Manifesto dos Tratados de Arquitetura em Vila Rica Setentista: O pórtico toscano do Palácio dos Governadores de José Fernandes Pinto Alpoim |95

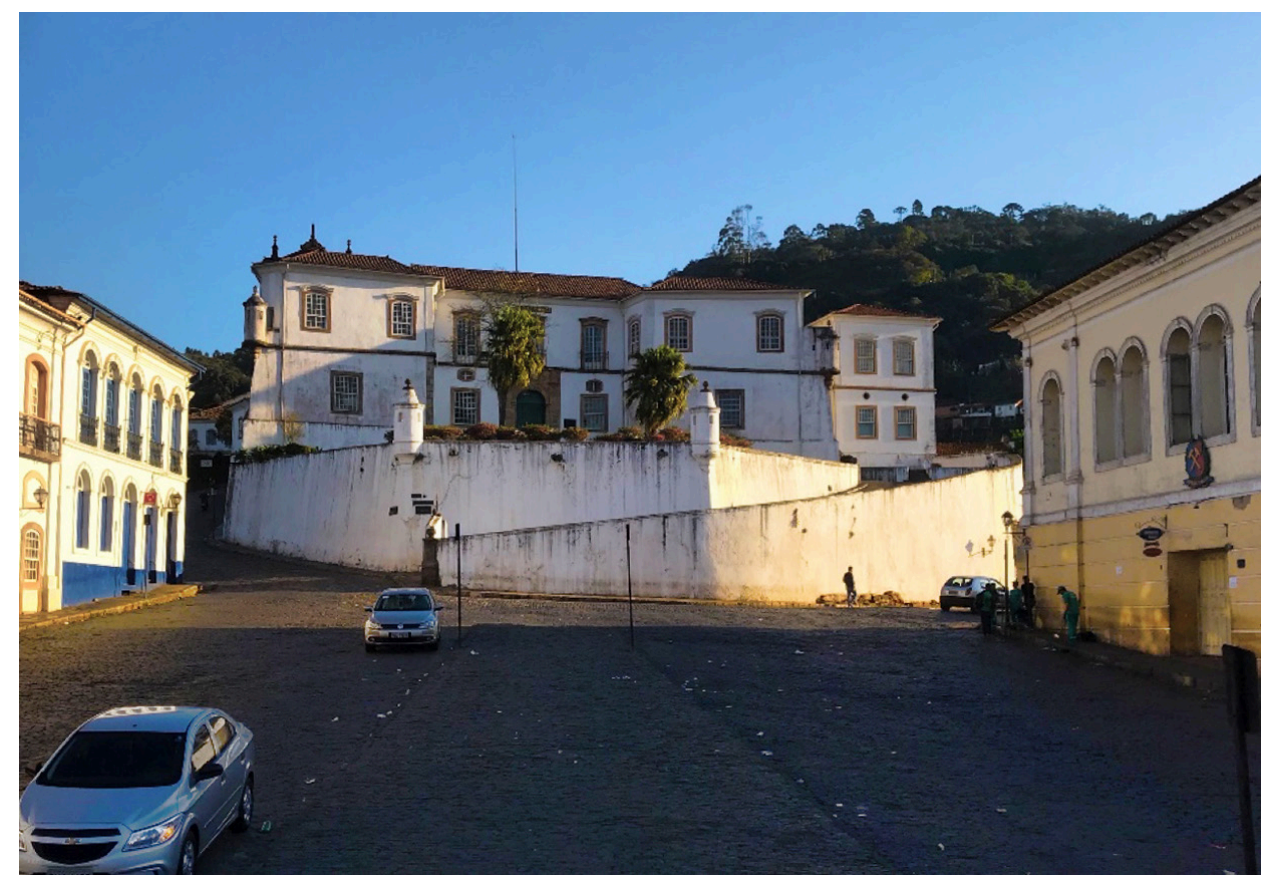

Figura 1 (topo): Ouro Preto, Museu de Ciências da UFOP, antigo Palácio dos Governadores, elevação principal. Fonte: Foto Ronaldo Costa, 2018.

Figura 2 (à direita): Ouro Preto, Museu de Ciências da UFOP, área central da elevação principal com o pórtico de entrada. Fonte: Foto Marcos Tognon, 2018.

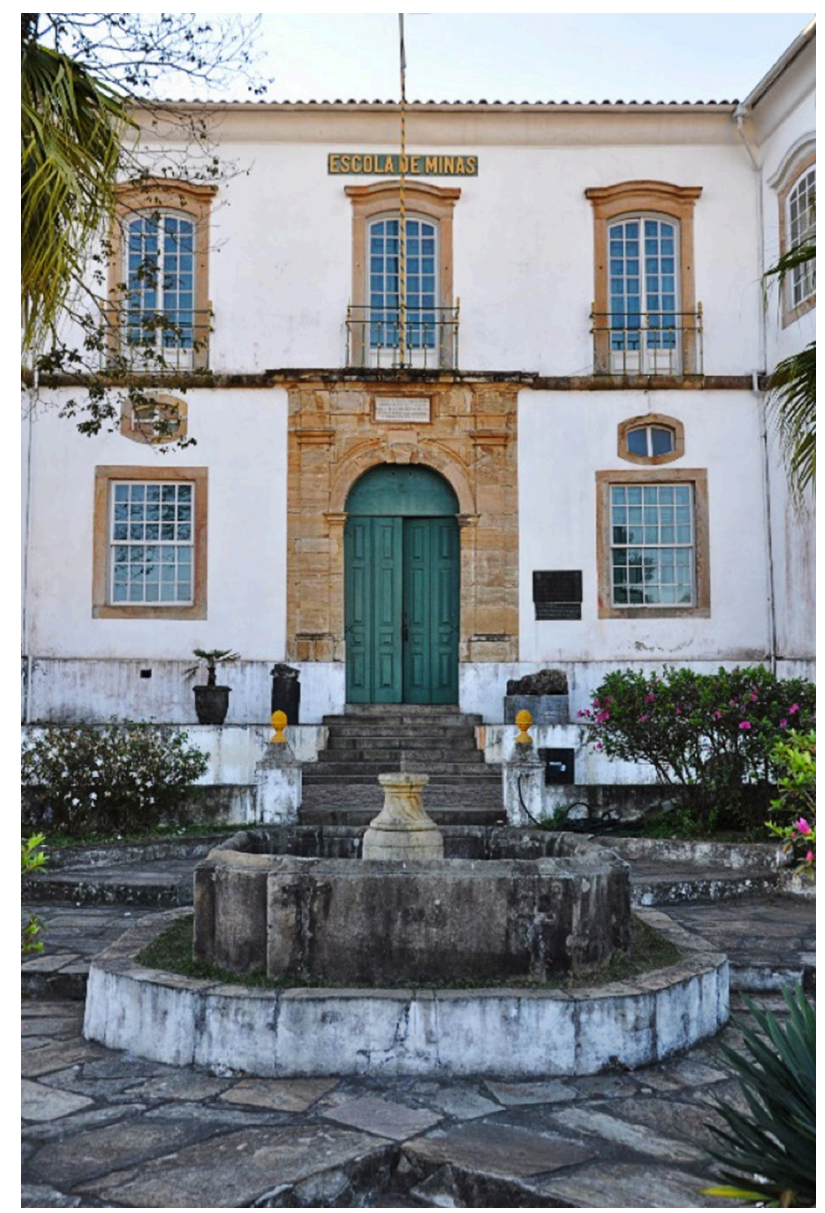


Dias, cujo sítio arqueológico foi escavado em $1973^{5}$. Mas ambos não avançam em teses que hoje nos parecem óbvias: que o Palácio dos Governadores construído com a cal - "melhor do país" - e areia na moldagem de alvenarias de pedra argamassada com "quatros palmo de grossura" 6 no térreo, empregando a boa cantaria de nos batentes de portas e janelas, no cordão entre os andares, seria a obra exemplar para as futuras construções da segunda metade do século XVIII, abandonando o padrão das arquiteturas de terra trazidas pelos primeiros ocupantes paulistas; que o mais significativo construtor arrematante do Palácio, o português Manoel Francisco Lisboa, se afirmara nessa ocasião como o profissional construtor que introduzirá a "monumentalidade lítica" em Vila Rica setecentista ${ }^{7}$, somando-se as suas futuras obras da Casa da Misericórdia, do templo da Venerável Ordem Terceira do Carmo, o Chafariz do Alto de Santa Efigênia; uma terceira tese na qual a edificação do Palácio dos Governadores seria a ocasião para iniciar um "ajuste" decoroso da topografia acentuada desse patamar entre os arraias, praça aberta no Morro de Santa Quitéria que visará, paulatinamente, uma centralidade urbana da vila tentacular, nascida pelas bocas de minas e se acomodando entre os poucos e naturais terraplenos de Padre Faria até a subida de Cabeças, eixo de leste a oeste da Vila Rica ${ }^{8}$.

Três entre outras inúmeras e ricas teses que, na leitura dos já citados documentos publicados pelo Arquivo Público Mineiro, corretamente empregados por Ivo Porto Meneses e Francisco Antonio Lopes, poderiam nos levar a estudos mais aprofundados do próprio léxico burocrático pertinente à descrição dos contratos e acordos de comissionamento das obras nessa primeira metade do século XVIII. "Taipa", "pau apique", cantaria de "picão miúdo", estuques "fasquiados polegada cheia por vazio", "telhado amouriscado", "simalha erguida [à] romana", como também "verga [à] romana" são algumas das designações construtivas e estilísticas contidas nos "Apontamentos" do engenheiro Alpoim nos memoriais de contratação lavrados pelo secretário do Governador e Capitão geral do Rio de Janeiro e das Minas Gerais entre 1741 e $1742^{\circ}$, e, relevantes para evidenciar uma densa cultura de aferição estética e técnica estabelecida na gestão dos empreendimentos do Estado português.

Toda essa demanda e cuidado no maior empreendimento construtivo do governo de Dom João $V$ em Vila Rica se justificava pela monumental expectativa da nova urbis redentora, celebrada quase dez anos antes, no triunfo Eucarístico de 1733:

[...] de trinta anos ao presente se mostrou aos portugueses a América coroada de ouro nas altíssimas, e ao princípio impenetráveis serranias das minas do Brasil, onde a providência divina, ou a mesma natureza por destino imperceptível ao juízo humano, mostraram terem em depósito guardadas imensas riquezas no interior dessas serras; [...] A exuberante cópia do ouro destas minas deu logo um estrondoso brado cujos ecos soaram nos mais distantes, e recônditos seios de toda a América; alteraram a muitos moradores do Brasil a cultura dos campos; fizeram outros vacilantes; a muitos nos cabedais inferiores, e outros oprimidos da necessidade fizeram sair a este zênite da riqueza: convidando a uns com esperança de melhoras, a outros com princípio de prosperidade; e porque os primeiros habitantes do trabalho do caminho passaram logo à felicidade da fortuna, quase ao mesmo tempo, ou com pouco intervalo, vendo, e habitando a terra, e possuindo a afluência do ouro, em breve tempo das cidades e lugares marítimos sobreveio inumerável multidão; uns com cobiça de fácil fortuna, outros anheiando remédio à necessidade. ${ }^{10}$ 
O Conde de Bobadela, assumindo as províncias do Rio de Janeiro, São Paulo, Minas Gerais e regiões do Sul do Brasil em 1736, só poderia convocar a patente mais graduada, o engenheiro saudado por El Rey como "Sargento Mor" da nova Aula de Artilharia e Arquitetura Militar no Rio de Janeiro para elaborar o projeto e demais orientações na construção do novo Palácio dos Governadores, José Fernandes Pinto Alpoim (1700-1765). ${ }^{11}$

Não temos uma detalhada monografia sobre as obras arquitetônicas projetadas por Alpoim que chega ao Brasil em 1738, atua em Minas Gerais entre 1741 e 1742, visita os confins de Mato Grosso, do Rio Grande do Sul entre outras províncias para demarcar fronteiras em relação à Espanha, atuando até sua morte com 65 anos de idade no Rio de Janeiro: mas aferimos estudos sobre a sua especialidade docente nas diversas funções da Artilharia ${ }^{12}$, uma breve listagem das edificações nas quais projetou ou reestruturou ${ }^{13}$ sob o comando do Conde de Bobadela, e especialmente, pesquisas que destacam a densa preparação intelectual e técnica do nosso Sargento-Mor real por meio das suas duas publicações, de 1744 e 1748, respectivamente, "Exame de Artilheiros" e "Exame de Bombeiros" 14.

Essa formação intelectual de José Fernandes Pinto Alpoim não poderia ter sido mais fortuita: aluno da Academia de Viana ${ }^{15}$, discípulo direto de Azevedo Fortes na Academia Militar de Lisboa ${ }^{16}$, usufruiu plenamente do clima instaurado por Dom João $\vee$ na qual Portugal se confrontou com as mais altas culturas europeias, e, no caso da Arte Militar, se abriu para a literatura especializada mais avançada, de forte cunho técnico, racionalista, cujo relato acadêmico do autor do "Engenheiro Português", endereçada a El-Rey, sintetiza esse engajamento:

"Como V Majestade foi servido promover-me ao posto de Engenheiro-mor destes Reinos, na esperança de que eu podia contribuir com algumas lições a se formarem sujeitos como capacidade de servir bem a V. Majestade, e estando também certo não terá deixado de chegar à Real notícia de V. Majestade o pouco fruto que se tem tirado da Aula, ou Academia das Fortificações desta Corte, me pareceu mui conforme à minha obrigação, e ao zelo que sempre tive, e terei do Real serviço de V. Majestade apontar o remédio, e a melhor forma, em que os sujeitos, que daqui por diante se aplicarem às lições das Academias Militares, se instruam, e capacitem naquela ciência; e V. Majestade tenha Engenheiros, de que se possa servir com utilidade. [...]

Um bom Engenheiro há-de ser um bom Soldado com disposição valorosa, criado com a doutrina e exercício Militar [...] finalmente esta palavra Engenheiro, quer dizer o Soldado pronto para todas as funções da guerra, ou seja ataque e defesa das praças obras de fortificação, alojamentos, ou entrincheiramentos dos Exércitos; ou seja para os aproches, ataques gerais ou particulares, etc., porque nele se deve achar disposição, estudo, ciência, e prática de todas estas coisas; e sem estas partes se Ihe não pode dar o nome de bom Engenheiro." 17

Alpoim chega ao Brasil como representante dessa geração de engenheiros ilustrados sob a batuta de Azevedo Fortes, e pela condução e vontade do Conde de Bobadela, realiza os projetos mais eloquentes do projeto joanino para estabelecer um novo eixo territorial de interesse da Coroa, entre Minas e Rio de Janeiro, entre a praça Tiradentes e o terreiro do Paço. É na futura capital da colônia brasileira, instituída 
Figura 3: Rio de Janeiro, Paço Imperial - IPHAN, fachada principal. Fonte: Foto Marcos Tognon, 2018. anos mais tarde pelo Marques de Pombal em 1763, que Alpoim fará o projeto do hoje Paço Imperial para abrigar seu tutor Gomes Freire de Andrade ${ }^{18}$. Palácio do Governador que teve inúmeras reformas e ocupações nos últimos 250 anos, mas cujas características construtivas foram, em parte recuperadas com o restauro dos anos de $1980{ }^{19}$. [Figura 3]

A sobriedade das estruturas murárias brancas, em contraste com as cantarias em pedra natural que demarcam a linguagem clássica de arcos, pilastras e pilares, portais de ingresso, de batentes para portas e janelas, de cornijas e cordões que demarcam os pavimentos evidenciam tramos/blocos horizontais, atestam, por fim, a evidente intenção do sargento-mor Alpoim em promover a visibilidade da firmitas edilícia de modo muito explicito, racional. Essa mesma estratégia compositiva, projetual, foi celebrada em outras obras do sargento-mor no Rio de janeiro como nas fachadas do demolido Convento Nossa Senhora da Ajuda, do Convento de Santa Tereza, nas obras para a passagem arqueada do Teles, no remodelado claustro dos beneditinos.

Outra obra importante, hoje demolida, de Alpoim no Rio de Janeiro foi o Convento dos Barbonos, sede dos frades capuchinhos, foi projetado em 1740, um ano antes do nosso Sargento-mor seguir para Minas Gerais 20, e é, por ora, a única edificação com projeto completo registrado e recuperado no Arquivo Histórico Ultramarino de Lisboa: edificação polifuncional em uma única massa edificada (capela, moradia dos frades, espaços de serviço e trabalho) cujo projeto é assentado em uma única prancha, demonstrando o pleno domínio de detalhes construtivos (ver o cuidado no desenho verossímil de envasaduras de janelas e portas, os ornatos e aspectos decorativos da fachada da "Capelinha", a estrutura em Asna com linha reta do telhado no "perfil"

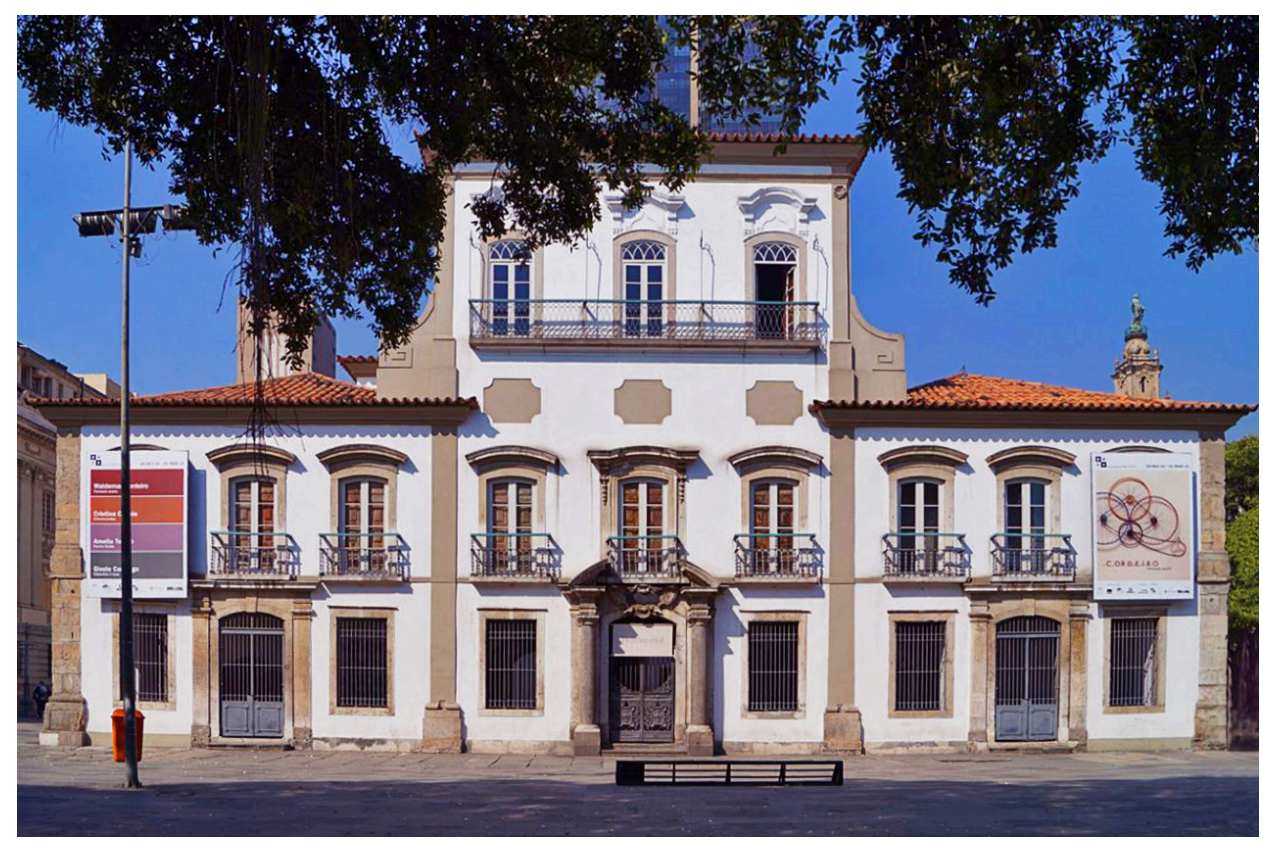


Figura 4: Rio de Janeiro, Projeto para o Convento dos Barbonos, apresentação do conjunto, desenho e aquarela, c. 1740. Fonte: site do Arquivo Histórico Ultramarino - Lisboa.

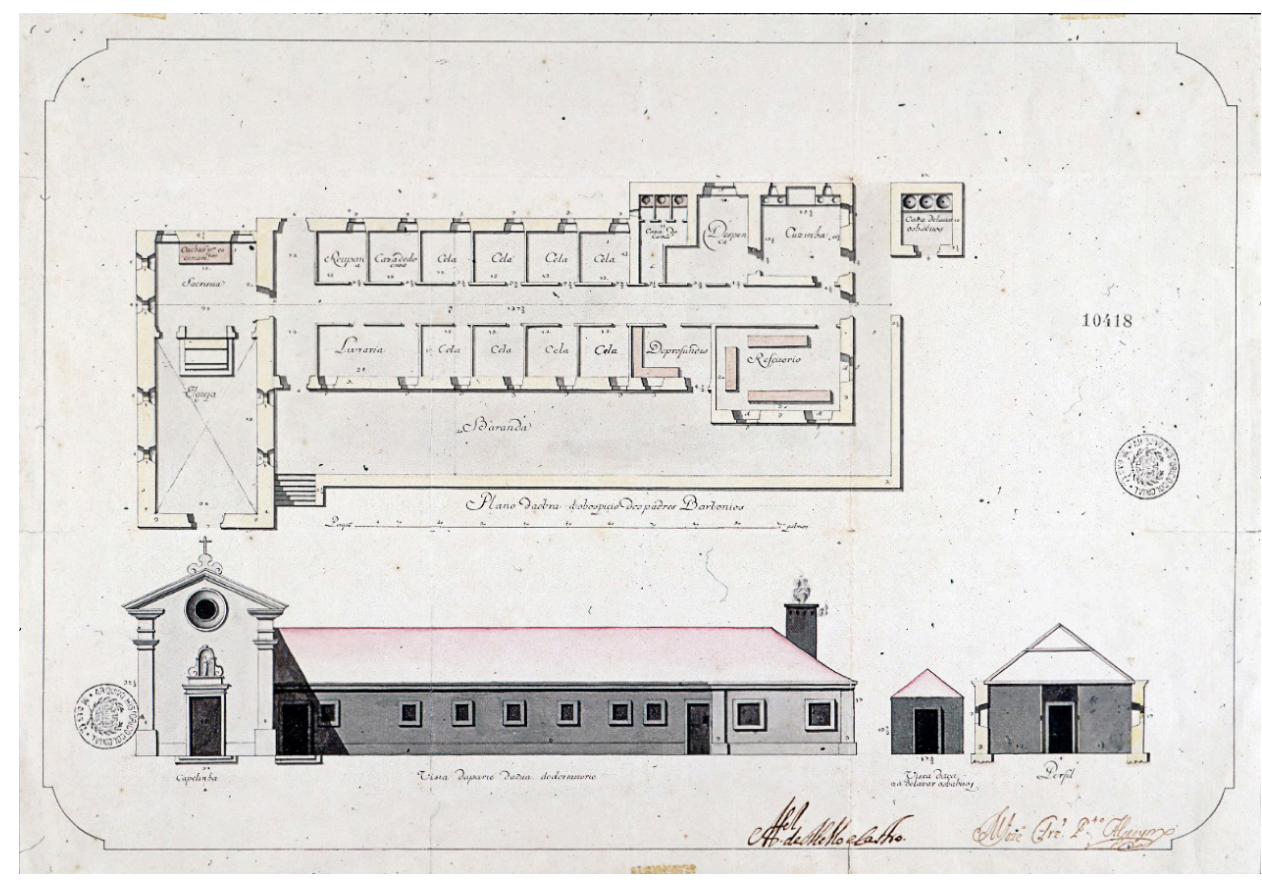

da "Casa de lavar os hábitos") planta devidamente assinada e regida pela escala do petipé "Plano da obra do hospício dos padres Barbonios". [Figura 4]

O Palácio dos Governadores em Ouro Preto, obra central dessa nossa comunicação, estaria, portanto, alinhado a essas posturas de projeto cultuadas pelo Sargento-mor José Fernandes Pinto Alpoim, posturas "severas" se confrontadas com as edilícias barrocas cariocas ou mineiras, mas discretamente eloquentes na evidência linguística, plástica e construtiva, baseada na grande Tradição Clássica arquitetônica acumulada por tratados, obras e lições no século XVIII europeu.

Essa "eloquência discreta" do projeto de Alpoim para a sede do governo em Ouro Preto foi, sucessivamente, obliterada tanto pelas alterações sucessivas na Praça Tiradentes e nos novos acessos rampantes promovidos antes da inauguração da Escola de Minas, como também pelas intervenções paisagísticas e omissões na conservação de seus atributos construtivos ao longo de todo o século XX.

Coube ao artista José Wasth Rodrigues nas primeiras décadas de 1900, sensibilizado pelo patrimônio colonial de Minas Gerais, o primeiro ato de reconhecimento da originalidade do Palácio dos Governadores de Ouro Preto, dos seus atributos ${ }^{21}$ e, destacadamente, do seu pórtico de ingresso ${ }^{22}$. [Figuras 5 e 6]

\section{Razões para uma Fortaleza em Vila Rica nos Setecentos}

O que explicaria o monumental investimento do Conde de Bobadela, logo nos primeiros anos de sua gestão das províncias do sudeste da colônia, ao promover a fábrica fortificada na então praça do pelourinho em Vila Rica? 


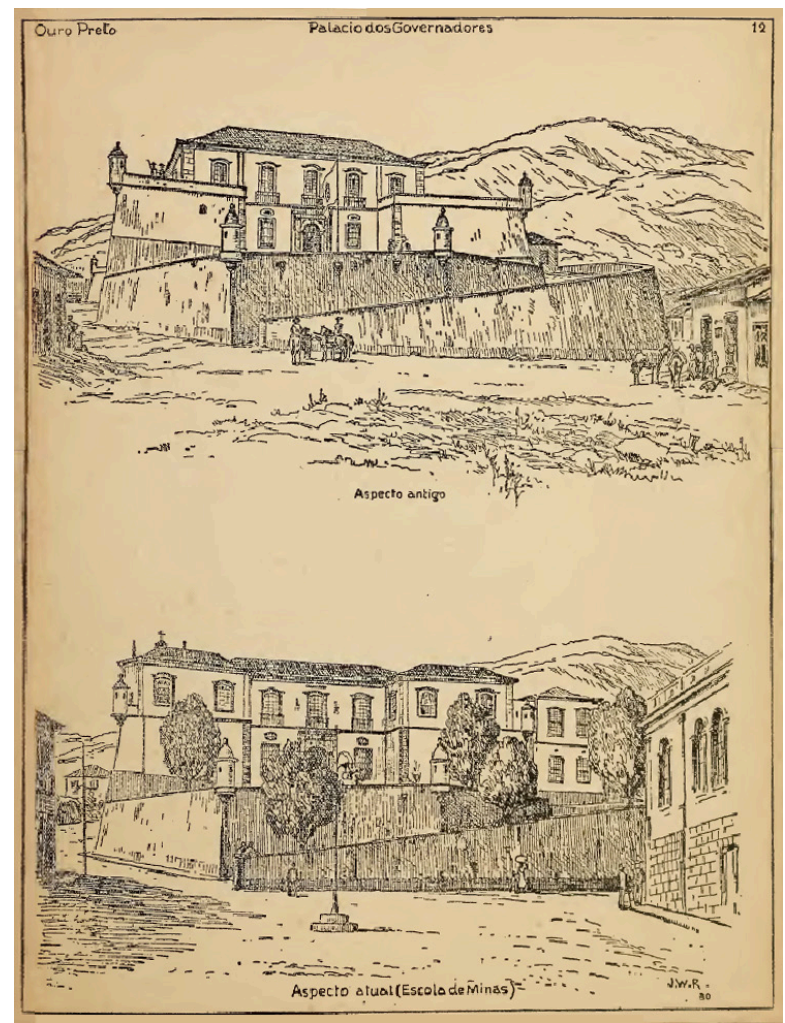

Figura 5: Jose Wasth Rodrigues, "Palácio dos Governadores - aspecto antigo e aspecto atual" Fonte: Documentário Arquitetônico, 1944, prancha 12

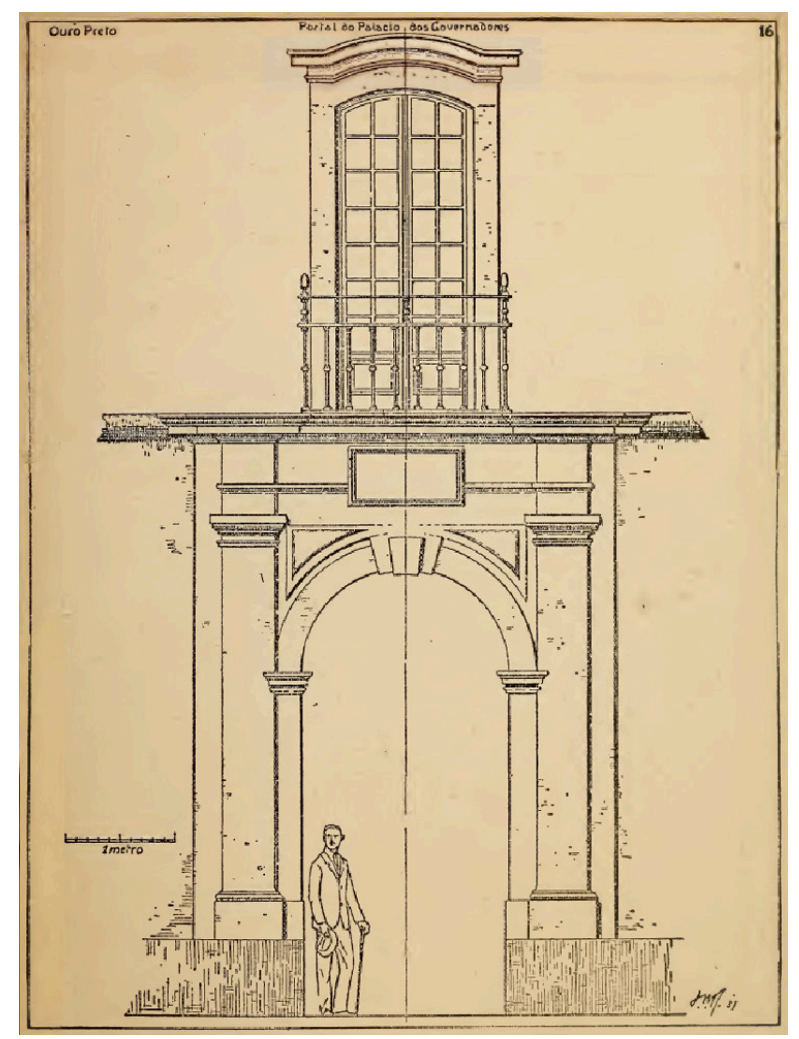

Figura 6: Jose Wasth Rodrigues, "Portal do Palácio dos Governadores". Fonte: Documentário Arquitetônico, 1944, prancha 16. 
Os habitantes de Minas já tinham testemunhado a vontade de D. Lourenço de Almeida, governante da província entre 1721 e 1731, na edificação do Forte de São José no rio das Velhas, região do Jaguará, cuja planta fora aprovada em Lisboa perto de 1730 e, por isso, talvez primeira edificação de cunho moderno militar da região, com sistema de baluartes, "explanada com 8 peças de artilharia", fosso, "pórtico" monumental de entrada, casa de munições, quarteis para as autoridades políticas e militares. ${ }^{23}$

De fato, o Palácio dos Governadores a ser edificado na vila cabeça da província mineira pode ser compreendido como uma das mais fortes estratégias que efetivaram a missão dada ao Conde de Bobadela pelo Reino português de D. João V: instaurar, disseminar, impor a ordem pública no meio social daquela parte da colônia brasileira que, ambiguamente, se mostrava como a recompensa econômica finalmente advinda à Portugal nos empreendimentos do Atlântico Sul, e, ao mesmo tempo, se apresentava incontrolável aos olhos de Lisboa, pelas revoltas e pela violência de vários episódios nos primeiros anos de ocupação dessa terra.

Desde os seus "descobridores" paulistas, que chocavam os viajantes estrangeiros pela sua postura furtiva e rebelde ${ }^{24}$, as vilas e povoados gerais da mineração tinham testemunhado várias eclosões sociais nas primeiras décadas do século XVIII; quando Gomes Freire de Andrade assume em 1733 o governo de São Paulo, Minas e Rio de Janeiro, já constava na memória dos seus súditos pelo menos dois conflitos que sobrepunham não só diferenças de etnias, de ambições sobre o controle das catas e bocas de mineração, mas também de rebeldia ao pagamento de tributos à Coroa, a "guerra dos emboadas" e a "revolta de Felipe dos Santos" 25 . O Conde de Bobadela ainda verá a "sedição de 1736" ser combatida por Martinho de Mendonça, no cargo interino de governador da capitania de Minas, revolta sangrenta no sertão do São Francisco, área de conflito permanente entre "mineiros" e "baianos" 26, a por conta da nova e regular cobrança de impostos de ganhos e propriedades, a "capitação" 27.

Logo, Gomes Freire de Andrade, ao seu retorno às Minas em 1737, não pretendia passar pelas mesmas dificuldades que o Conde de Assumar, precariamente instalado entre a Vila do Carmo e Vila Rica e pautado por um sangrento combate aos revoltosos liderados por Pascoal da Silva Guimarães e seu serviçal Felipe dos Santos em meados de $1720^{28}$. Assim, contra a instabilidade social, contra a rebeldia no dever dos tributos à Coroa, contra a violência "natural" instigada pela rusticidade do território ainda desbravado de matas e minas da capitania dos diamantes e do ouro, contra a fome e as calamidades que acudiam os moradores e viajantes ${ }^{29}$, o Conde de Bobadela inicia uma densa política de pacificação, de imposição e visibilidade do Estado português joanino pela arte de edificar pontes, chafarizes, calçamentos, cadeias, estimula a construção das capelas das irmandades ao longo da vila, inicia a pavimentação da Estrada Real, e, como peça chave desse movimento, promove a ordenação da praça central da capital provinciana pelo fortificado Palácio dos Governadores. ${ }^{30}$

Ao ser convocado para "subir" até Minas Gerais com o Conde de Bobadela em 1741¹, o sargento-mor José Fernandes Pinto Alpoim elabora um projeto de fortaleza com quatro baluartes em seus ângulos retos, uma solução formal de "praça fortificada regular" já consolidada em muitos exemplares na colônia brasileira ${ }^{32}$, e, sobretudo, na literatura técnica dos engenheiros militares ${ }^{33}$. 
Figura 7 (esq.): "Planta de hua fortaleza, ou Praça fortificada com baluartes", construção geométrica do perímetro, Luis Serrão Pimentel (1680). Fonte: (PIMENTEL, 1680) - Luís Serrão Pimentel. Methodo Lusitanico de Desenhar as Fortificações. Lisboa, 1680.

Figura 8 (centro): “Da Fortificação regular do Cavaleiro Antonio De Ville", planta com sistema retangular com sistema de forros, Manoel de Azevedo Fortes (1729). Fonte: (FORTES, 1729) - Manoel de Azevedo Fortes. O Engenheiro Portuguez. Lisboa, 2v., 1728-1729.

Figura 9 (dir.): "Praça regular", variações dimensionais e geométricas na construção dos baluartes, Diogo Sylveyra Vellozo (1743), editada por Mário Mendonça de Oliveira (2005). Fonte: (VELLOZO, 1743) - Diogo da Sylveyra Vellozo. Arquitetura militar ou fortificação moderna. Transcrição e comentários de Mário Mendonça. Salvador: EDUFBA, 2005.
Delimitando nossas referências aos três tratados mais importantes da Arte edilícia militar escritos por portugueses, o "Methodo Lusitânico de Desenhar as Fortificações" (Luiz Serrão Pimentel, Lisboa 1680), "O Engenheiro Portuguez" (Manoel Azevedo Fortes, Lisboa 1728-1729), e "Arquitetura Militar ou Fortificação Moderna" (Diogo Sylveyra Vellozo, manuscrito de $1743^{34}$ ), entre centenas de textos circulando pela Europa desde o século XVI, veremos que o plano geral do Palácio dos Governadores de Alpoim favorece mais concessões à moradia palaciana e à burocracia oficial que aos elementos próprios de defesa fortificada. [Figuras 7 e 8 e 9]

Os baluartes do Palácio do Governador Gomes Freire de Andrade são bem retraídos, não avançam significativamente rumo ao sul na então Praça do Pelourinho; suas faces térreas para a praça, de fato, são quase paralelas à elevação do corpo assobradado central, o que facilitou, inclusive, a ocupação volumétrica harmoniosa desses bastiões já na segunda metade do século XVIII pela Capela construída pelo governador Antônio Noronha. ${ }^{35}$ São poucos os indícios remanescentes da arquitetura abaluartada hoje do Palácio dos Governadores, na qual podemos perceber ainda a altura do parapeito original, as cantarias reforçadas de ângulo. [Figura 10]

Os baluartes de Alpoim são mais simbólicos que eficientes em termos de artifício construtivo defensivo como tão bem formulou o Conde Vauban ${ }^{36}$, são valores visuais, mais do que funcionais, da vigilância permanente do Governador, da austeridade militar, e, marca da robustez edificada da coroa joanina capitaneando o lado setentrional da atual Praça Tiradentes. Assim descreveu o sargento-mor em seus apontamentos para a contratação das obras dessa "arquitetura simbólica":

"O plano superior dos baluartes ficará por sima do cordão, cujo plano será lageado com declive para o parapeito, $p$. deitar as agoas fora $q^{\prime}$ Ihe choverem. Estes baluartes serão cheyos de terra, e socados por conta da real fazenda, e batidos, e apiloados, athe ficarem repudiano o pilão. Os parapeitos desses baluartes serão por sima do cordão feitos de albenaria com dous palmos e meyo de grosso, e quatro e meyo de alto, cobertos com suas capas de lageado por cima, que exceda hua polegada para a banda de fora, outra para a banda de dentro, terão esses parapeitos nas suas rais escoos, ou
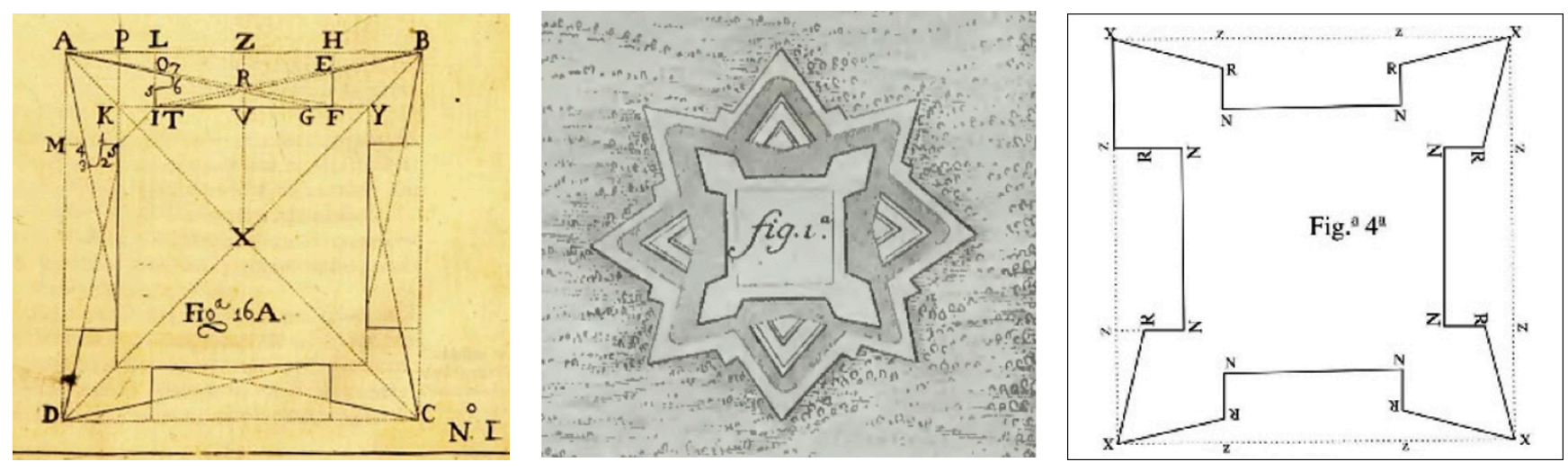
Figura 10: Ouro Preto, Museu de Ciências da UFOP (antigo Palácio dos Governadores), detalhe do baluarte leste na elevação lateral. Fonte: Foto Marcos Tognon, 2018.

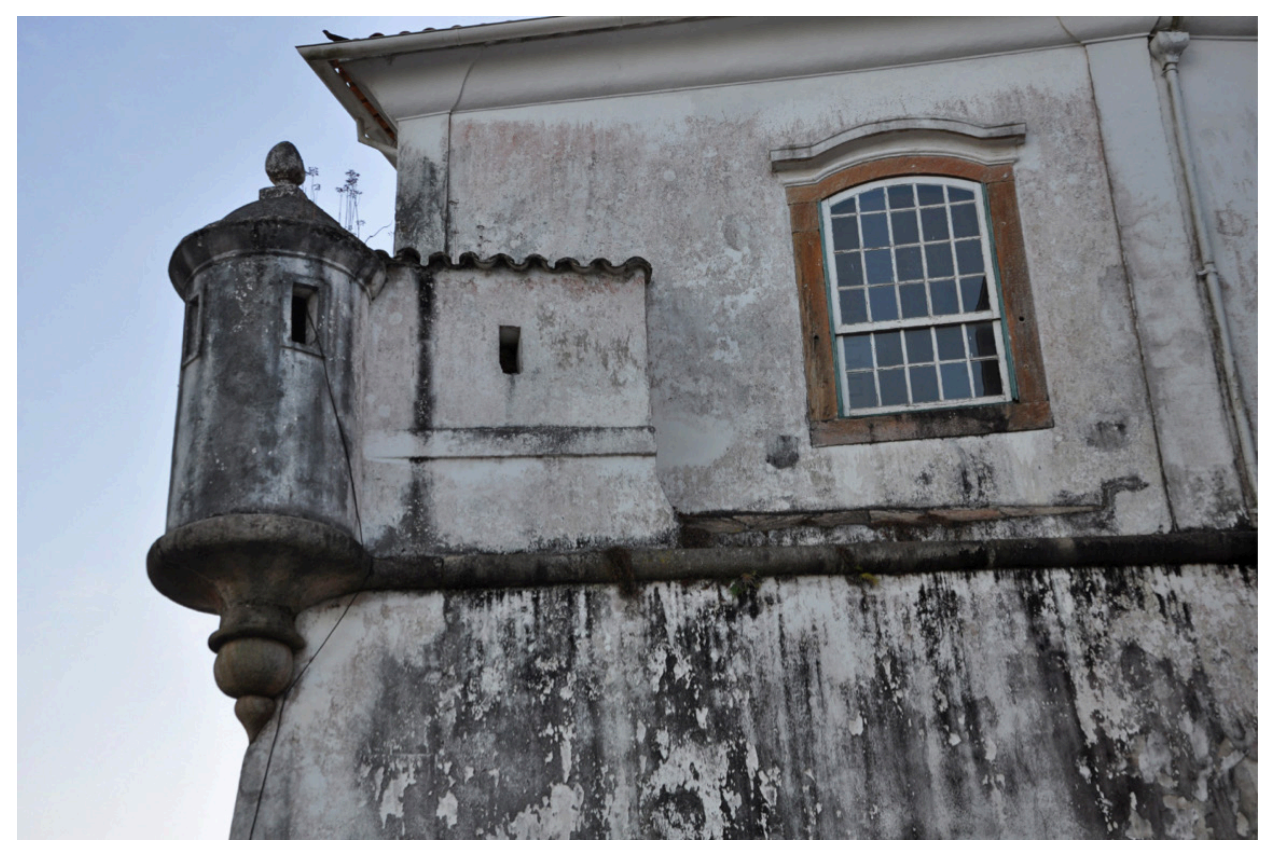

buracos para darem sahida as aguas, q' senão emsopem no terrapleno. [...] Nos anglos flanqueados dos quatro baluartes haverá em cada hum uma guarita redonda, fundada sobre o seu pião também redondo, estas guaritas terão as larguras, grossuras, e alturas, e mais ornamentos q' mostra a planta levarão, sua porta, e três frestas de dous palmos de alto, e meyo largo com seus rasgos para dentro, e para fora serão de tijolo. " 37

Os baluartes frontais do Palácio dos Governadores serão em breve desterrados pelo mesmo construtor, Manuel Francisco Lisboa, em 1766 e com o objetivo de abrir uma sala de trabalho para os serviços de despacho oficial da Capitania ${ }^{38}$; esse episódio será o primeiro de muitas ampliações verticais e horizontais da mole e, consequentemente, veremos o cancelamento progressivo do valor formal e, porque não, simbólico dos baluartes até a implementação da sede da Escola de Minas na edificação de Alpoim ${ }^{39}$.

Após essas obras, e já sem a presença do Conde de Bobadela e Alpoim, falecidos respectivamente em 1763 e 1765, temos o primeiro e único registro conhecido da Praça Tiradentes, um desenho que está hoje no Instituto de Estudos Brasileiros da Universidade de São Paulo ${ }^{40}$, sem título e sem registro de autoria, mas o único documento que traz a representação do Palácio dos Governadores antes das grandes obras de ampliação e das rampas frontais. [Figura 11]

Nessa vista elevada da área central e norte da Praça do Pelourinho, embora a perspectiva não tenha projeções corretas, de fuga, que garantam as devidas proporções e escalas dos edifícios entre as elevações leste e oeste, podemos notar os três níveis desse grande espaço, todos em declive para o sul, para o observador portanto, desde o talude aos pés do Palácio fortaleza ao fundo até a igreja de Santana (à direita com duas torres sineiras) e à pequena edificação de porta e duas janelas (à esquerda), passando para a faixa à esquerda regular em sua pendência e, por fim, ao terceiro nível, mais baixo 
Figura 11: OURO PRETO, Praça Tiradentes (hoje), vista para o Palácio dos Governadores, entre 1766 e 1781. Fonte: Acervo IEB-USP.

Figura 12: "Mappa da Villa Rica", área central com a Praça Tiradentes (hoje), detalhe de mapa, letra A: Palácio dos Governadores, c. 1775 e 1800. Fonte: publicado por Nestor Goulart Reis 2000, p. 215. de todos e, portanto, delimitado por estruturas murárias de contenção, criando um patamar para a tropa em revista na cena. Dois atributos urbanos são latentes, além do nosso Palácio ao fundo: o chafariz sobre um dos muros de arrimo para o adro da Igreja de Santana, e a coluna do Pelourinho, em cantaria ${ }^{41}$. Encerrando a vista em profundidade está o Palácio dos Governadores, cujas caraterísticas construtivas datam esse desenho custodiado no IEB entre 1766 e 1781, muito provavelmente da década de $1770{ }^{42}$, documento que é contemporâneo de um outro registro histórico, o "Mappa de Villa Rica", traçado por Manoel Ribeiro Guimarães e depositado no Arquivo Histórico do Exército Brasileiro ${ }^{43}$. [Figura 12]
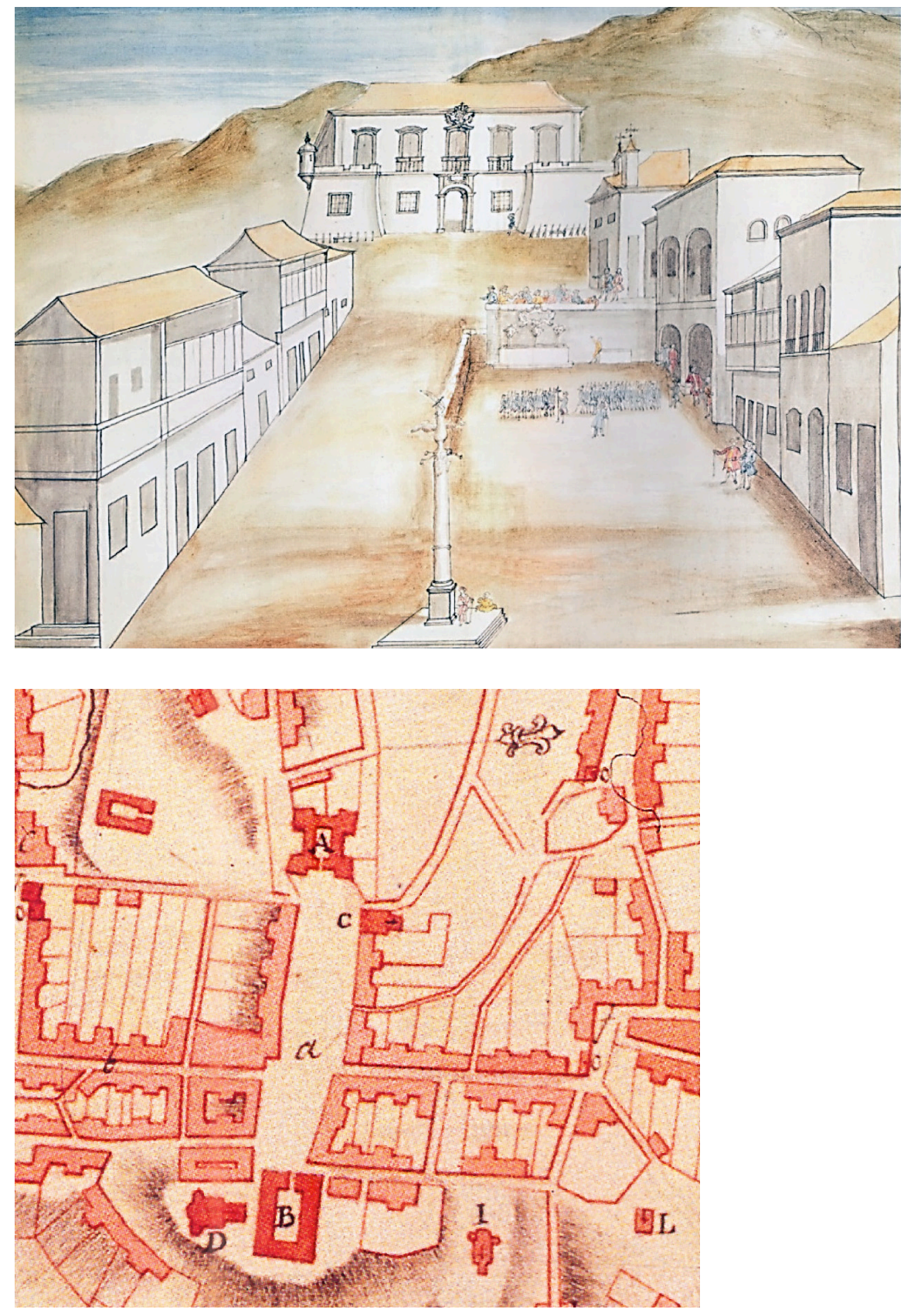
Figura 13: OURO PRETO, Praça Tiradentes (hoje), detalhe do Palácio dos Governadores, entre 1766 e 1781. Fonte: Acervo IEB-USP.
Se o "Mappa" nos revela, na área da sua "praça", a presença de uma fortaleza ainda com seus avantajados baluartes e a nítida demarcação da rampa de acesso pelo adro da Igreja de Santana, a vista do IEB, em detalhe, nos oferece informações talvez mais fidedignas sobre o Palácio dos Governadores, e especialmente, sobre o pórtico toscano de cantaria [Figura 13]: podemos notar que o nível de ingresso ao interior do palácio era alinhado com a base do pedestal da pilastra; vemos também o peitoril dos baluartes com ameias que alinhariam os canhões; e estão presentes a "targe" (cartela) assim como o brasão real de D. João $\mathrm{V}$, seguindo a descrição dos apontamentos de Alpoim em 1741:

"A porta principal terá nove palmos de largo, quinze de alto no seu vão será da ordem Toscana com todas as molduras, sacadas, e mais partes que mostra a planta. Levará hua targe com o letreiro como está na planta:

REYNANDO EL REY D. JOÃO V NOSSO SENHOR E SENDO GOVERNADOR E CAPITÃO GENERAL DO RIO, E MINAS GERAES O SARGENTO MOR DE BATALHA GOMES FREIRE DE ANDRADE.

Essas letras se darão nos mestres rematantes p.a as embutirem nas que tiverem abertas na dita targe. Sobre a simalha e no plumo do Pórtico levará as armas de El Rey com sua coroa imperial, e seus acompanhamentos, cujo risco se dará." 44

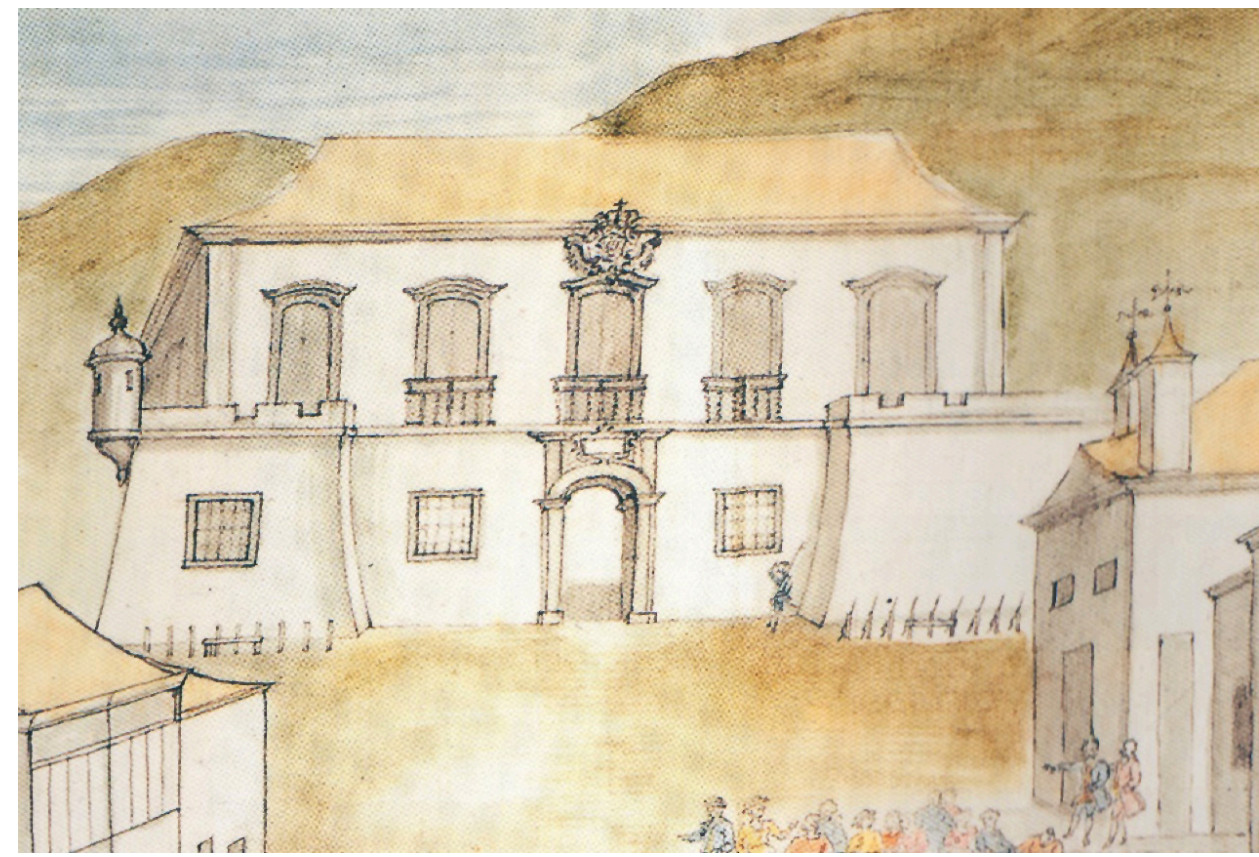


Figura 14: OURO PRETO, Escola de Minas, antigo Palácio dos Governadores, Pórtico de entrada, relevo geométrico e foto. Fonte: Marcos Tognon, 2018.

\section{O Pórtico Toscano e sua composição}

Com apoio da Escola de Minas e do programa de extensão Escola de Cantaria ${ }^{45}$, promovemos em 2018 uma fotogrametria e mensurações "in loco" da fachada do antigo Palácio dos Governadores, obtendo, especialmente, todas as exatas medidas dos componentes construtivos e formais do pórtico desenhado por Alpoim e construído, segundo registros de arrematação, por Caetano da Silva Ruivo no dia primeiro de julho de $1741^{46}$; executado em calcário dolomítico, uma pedra de fino grão e muito apta para o entalhe e desbaste ${ }^{47}$, o seu respectivo estado de conservação é muito precário, acumulando várias intervenções indevidas para colmatar antigas lacunas, fissuras, e evidentemente, sem nenhuma conservação preventiva de suas superfícies. [Figura 14]

A "ordem Toscana", como tema principal da composição arquitetônica do Pórtico de Entrada do Palácio dos Governadores, assumia uma recomendação expressa nos tratados de fortificação portugueses já referidos, entre quais Luis Serrão Pimentel em 1680:

"No que toca à fabrica dos Portaes deve ser no aspecto exterior algum tanto rude para que represente austeridade, \& horror significando assim ser a Praça invencível, \& formidável a seus inimigos.

Daqui veyo que os Portaes de alguas antigas Cidades se punhão Estatuas armadas, \& esculpião as bandeiras, \& despojos dos inimigos vencidos, ou outros finaes significativos de empresas grandes representando a Cidade inexpugnável, antiga, \& triunfal.

Por esta razão convem que sua fabrica seja da ordem Toscana ou da Dorica das cinco que a Arquitectura Civil está reduzida: da Toscana por ter muito de forte, \& robusta apta a sustentar todo o peso grave (diz Vincenzo Scammozzi ${ }^{48}$ ) \& que por tanto semelha o modo agigantando [...]" 49
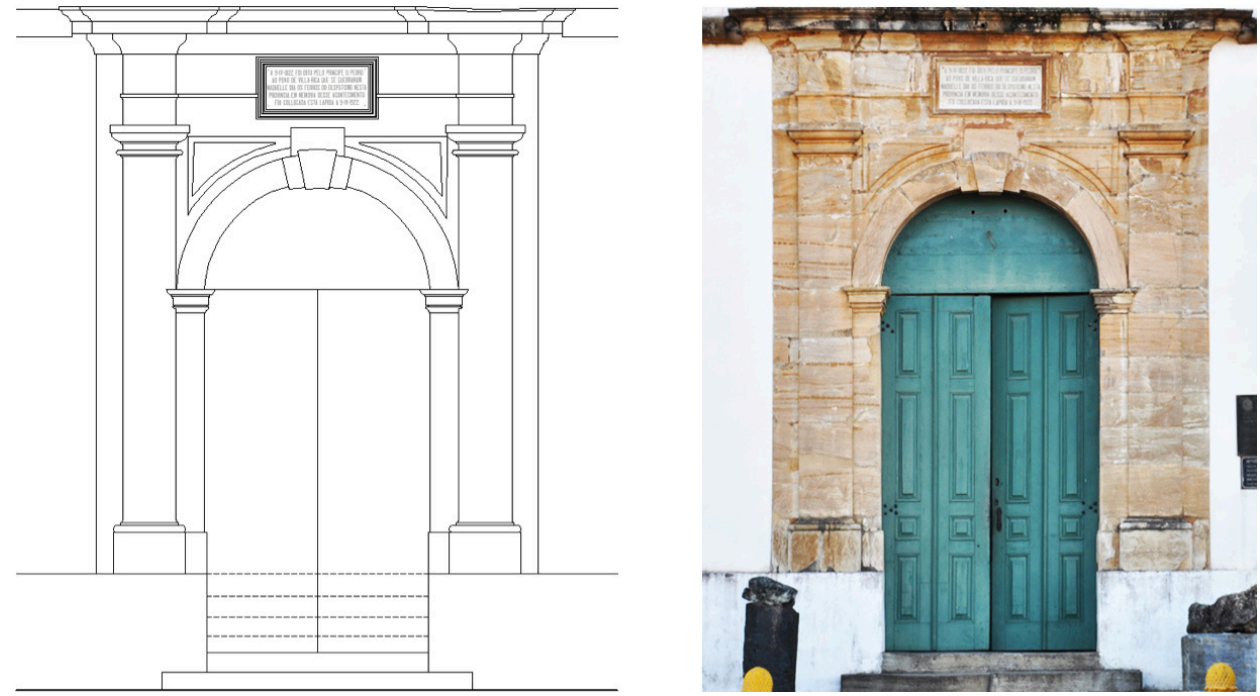
Manuel de Azevedo Fortes reitera tal prerrogativa toscana para a fisionomia das "portas principais" das edificações fortificadas:

"Todos concordão que as portas principaes para a serventia do povo, e guarnição, devem ser feitas no meio da cortina como fica dito: o seu aspecto deve ser horrido, que mostre fortaleza, e a sua architectura robusta: ordinariamente se servem os architectos da ordem Toscana, ou da Dórica, que tendo mais galhardia, nem por isso mais fraca." 50

Preceito que confirma um contemporâneo de José Fernandes Pinto Alpoim, o tratadista Velozzo, que escreve em 1743:

Todas as praças uniformemente necessitão de portas para serventia da guarnição e moradores, humas mais, outras menos, poque as de mediana grandeza Ihe bastarão duas, hu'a em correspondência da outra [...]

Fazem-se no meio das cortinas, por ser o lugar mais próprio para ellas, ou também mais encostadas a hum que a outro flanco, e dá a arazão o Methodo Luzitanico no cap. 35 pag. 147 para que fiquem fronteyras a alguma rua da praça, o que sempre se deve procurar por evitar o prejuízo, e dispêndio de demolir idificios. [...]

A sua fabrica deve reprezentar robustes, e valentia, e por isso escolherão os Architectos a ordem Toscana, por ser a mais valente das cinco ordens de Architectura civil; outros admitem a Dorica, porque alem de se compor de partes fortes e robustas, tem mais galhardia, e são mais aparatozas." 51

Como bem afirmara o saudoso professor Gabriele Morolli, no excelente livro "Vetus Etruria", a ordem Toscana se estabeleceria como a primitiva composição da linguagem de tradição clássica durante o Renascimento italiano, no século XVI, primeiro, frente às quatro ordens grego-romanas sucessivas, com sua austeridade nas modenaturas e proporções, e, ao mesmo tempo, explícita nos valores primordiais da tectônica monumental. Morolli aponta o livro 4 de Sebastiano Serlio como ponto de partida da elaboração dessa explicação discursiva e visual [Figuras 15 e 16] ${ }^{52}$, mas, será com o tratado de Vignola, desde a sua primeira edição de 1568, até as versões sucessivas, que teríamos a grande fortuna interpretativa e projetual da primitiva coluna e seus relevos ${ }^{53}$, conjunto que abrangerá, com sucesso, inúmeras fachadas e estruturas monumentais construtivas em todos os confins coloniais dos portugueses ${ }^{54}$.

Vignola não apenas oferece uma solução formal, com a justificativa cautelosa, para a linguagem Toscana, mas também propõe, a exemplo de todas as ordens historicamente comprovadas, indicações para a composição do tramo rítmico com arcada para esse primeira coluna, certamente outra inspiração de matriz serliana. Considerações entre a ausência ou a presença do pedestal podem indicar as proporções do entablamento, assim como da imposta na pilastra pé-direito do arco central. [Figura 17]

O pórtico de entrada do Palácio dos Governadores em Vila Rica demonstrava clara preferência pela discrição da Ordem Toscana, se compararmos outros pórticos de similar função, precedentes e posteriores, nas fortalezas brasileiras do litoral ${ }^{55}$. 
Figura 15: DE LE CINQUE MANIERE DE LI EDIFICl. Fonte: "Regole generali di Architettura...", S. Serlio, Livro IV, edição italiana de 1537, prancha 6.

Figura 16: TOSCANO. Fonte: "Regole generali di Architettura...", S. Serlio, Livro IV, edição italiana de 1537, prancha 7.
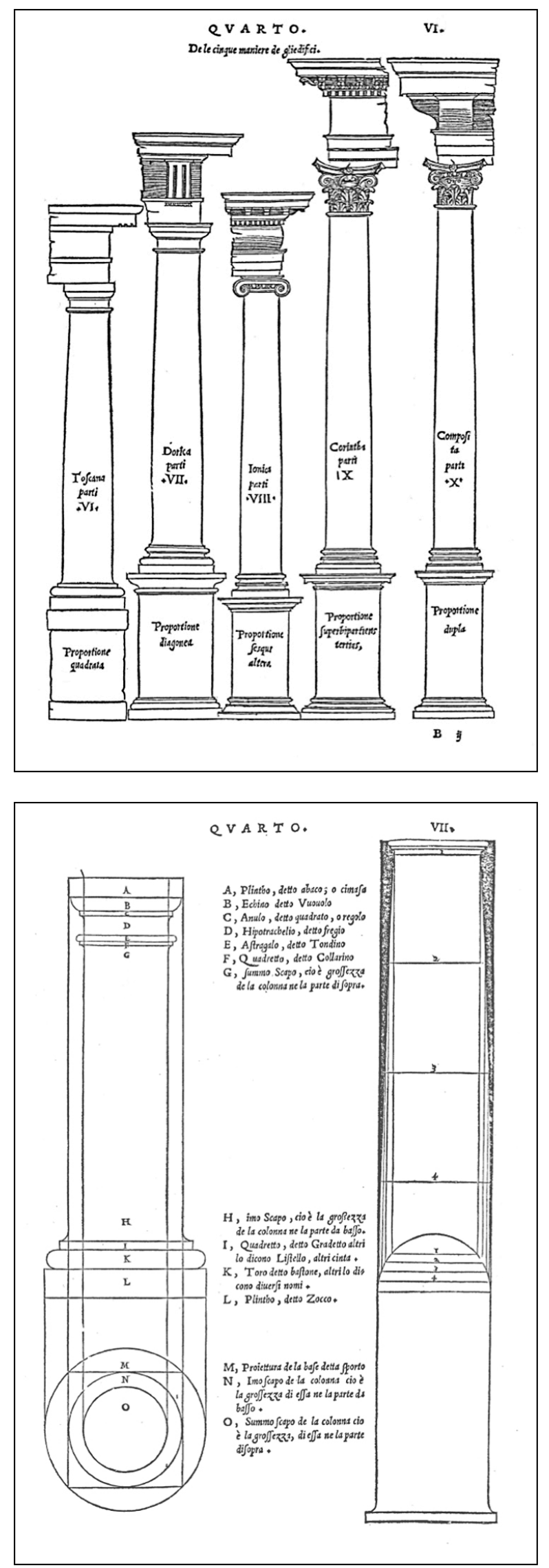

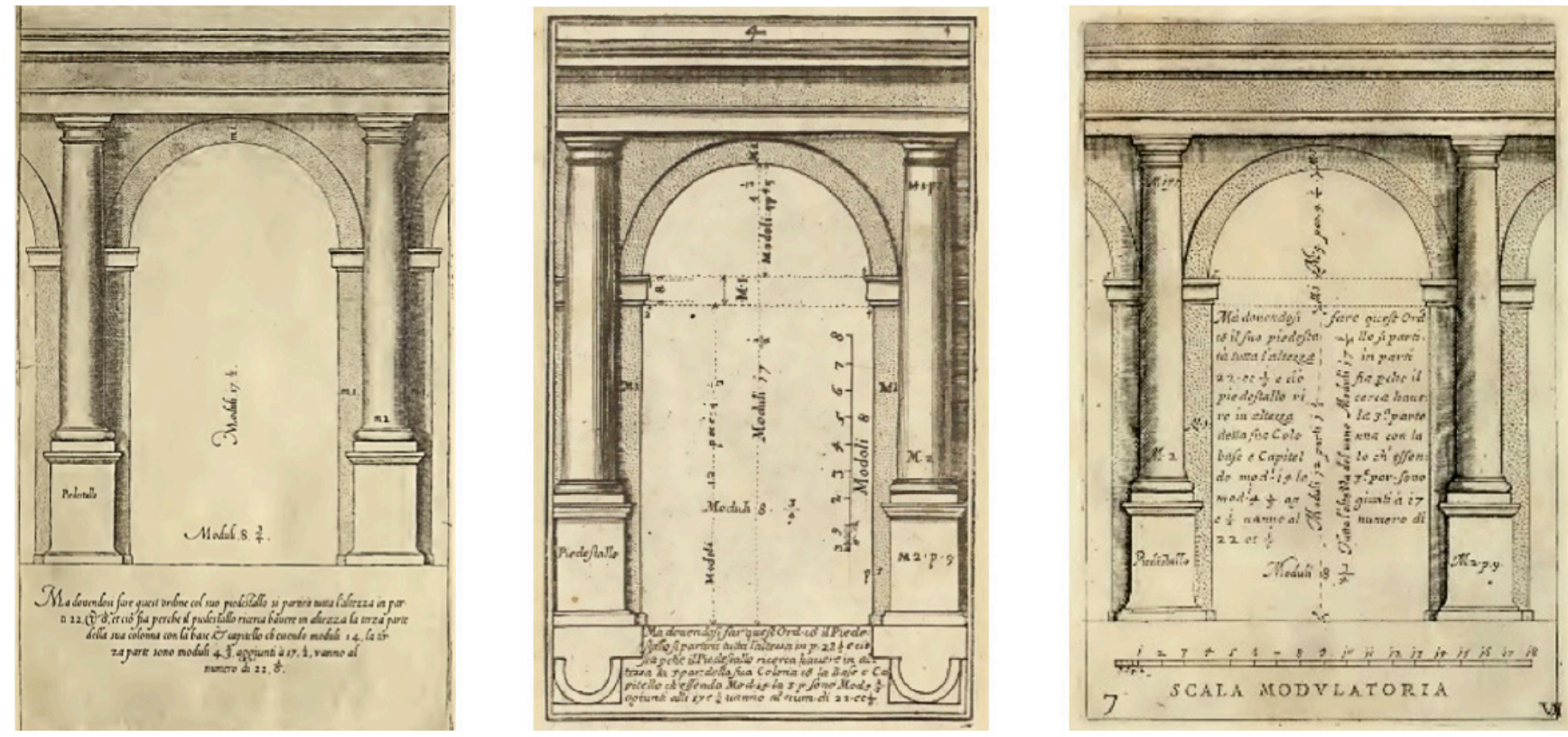

Figura 17: Pórtico Toscano. Fonte: "Regole dele cinque ordini d'Architettura ...", G. B. Vignola, edições italianas de 1563 (prancha 6), de 1692 (prancha 4) e de 1718 (prancha 7).
Mas as medidas e proporções do Pórtico de Vila Rica, seguindo as linha gerais já citadas de Alpoim, certamente apresentaram, pela primeira vez, no palco privilegiado da Praça Tiradentes, a matriz estruturante da linguagem clássica nas suas três regras assentadas na tradição construída desde o Renascimento: uso correto das modenaturas, peças, partes e ornatos; articulação gramatical hierarquizada entre seus componentes principais pilastra monumental, arco central abaixo da linha da arquitrave, entablamento completo (arquitrave, friso, cornija) coroando o sistema; emprego de relações proporcionais na delimitação formal de todos os seus recursos plásticos, sejam detalhes, fundos e, obviamente, as partes e corpos de primeiro plano. [Figura 18]

As medidas indicadas por Alpoim textualmente se referiam apenas ao vão central, que em parte corresponde aos nove por quinze palmos; e é desse vão central de nove palmos que, aplicando uma projeção proporcional quadrada com a sua altura (A), encontramos uma diagonal crescente, passando pelos perímetros externos das pilastras principais (B), e, por fim, até a altura total do pórtico toscano (C). As relações proporcionais podem também ser avaliadas, com medidas inteiras a partir do diâmetro das pilastras do arco central, na qual 20 módulos desse diâmetro correspondem à área quadrada nos dois eixos centrais, horizontal e vertical (de $\mathrm{D} \mathrm{a} \mathrm{G}, \mathrm{de} \mathrm{H}$ a I), restando ao vão efetivo de ingresso 8 módulos exatos (de E a F). [Figura 19]

Outro estudo de relações proporcionais que fizemos considerou o diâmetro do vão central (entre $\mathrm{M} \mathrm{e} \mathrm{N}$ ) ajustado no vértice do arco de passagem (J), que, reproduzido proporcionalmente até a altura da última linha do entablamento (K), demonstra um possível nível original do patamar de ingresso (L), nível perdido com as alterações da área frontal do Palácio dos Governadores ocorridas nos últimos duzentos anos. [Figura 20] 

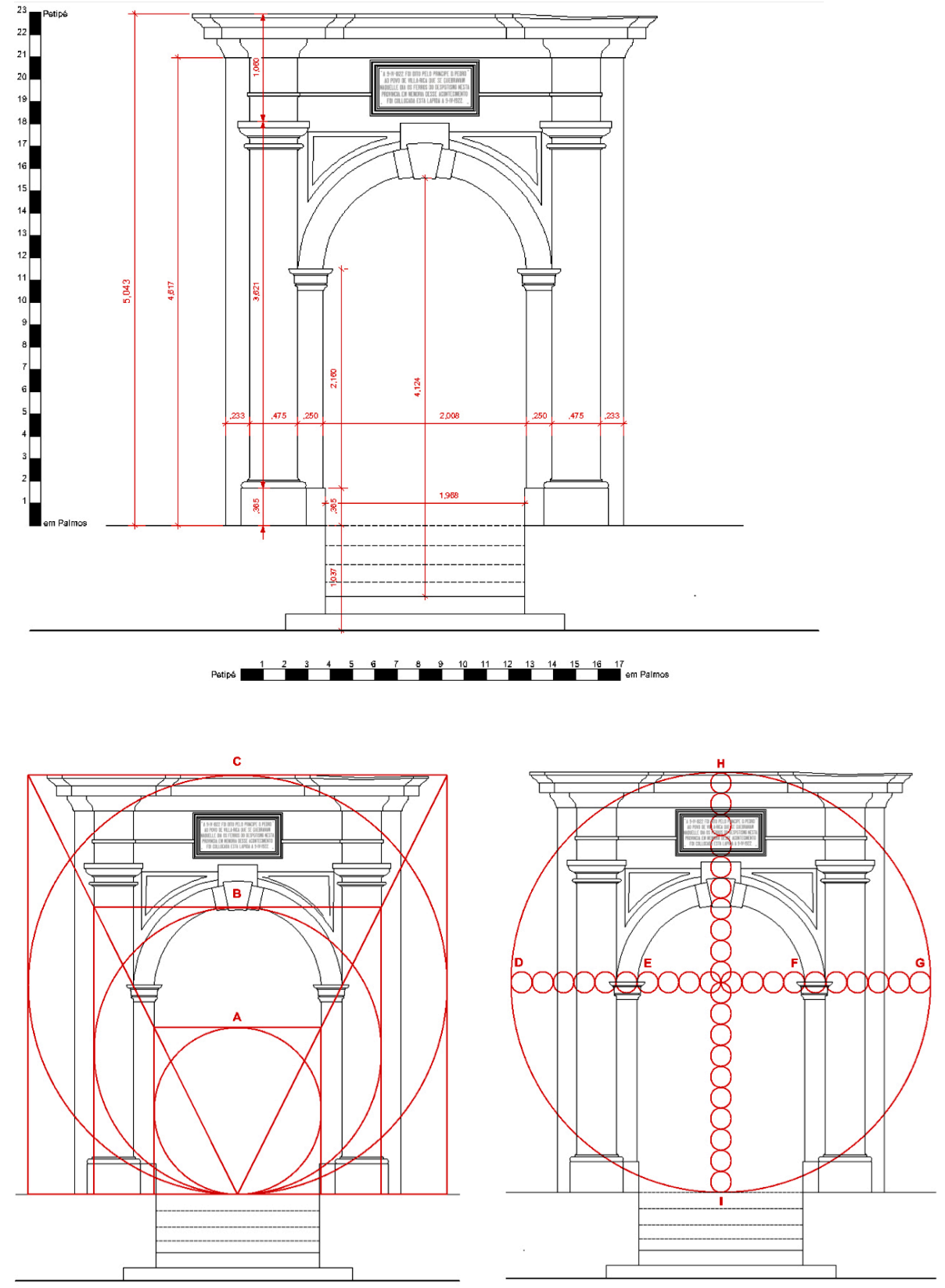

Figura 18 (topo): Ouro Preto, Escola de Minas - antigo Palácio dos Governadores, Pórtico de entrada, medias principais e escala de palmos. Fonte: Marcos Tognon, 2018.

Figura 19 (centro): Ouro Preto, Escola de Minas - antigo Palácio dos Governadores, Pórtico de Entrada, relações geométricas e modulares a partir do diâmetro da pilastra menor. Fonte: Marcos Tognon, 2018.

Figura 20 (embaixo): Ouro Preto, Escola de Minas - antigo Palácio dos Governadores, Pórtico de Entrada, relações geométricas entre a altura total e o vão de ingresso. Fonte: Marcos Tognon, 2018.

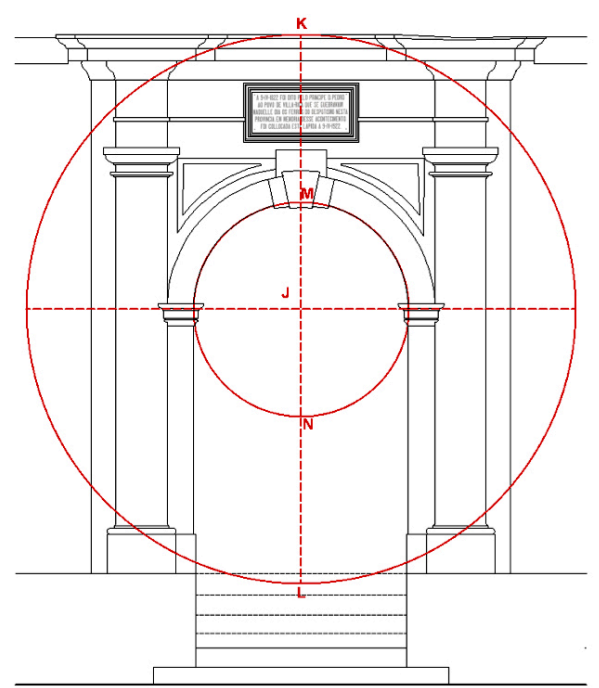


Figura 21: Ouro Preto, Escola de Minas - antigo Palácio dos Governadores, Pórtico de Entrada, relações modulares altimétricas das duas pilastras toscanas, menor e maior. Fonte: Marcos Tognon, 2018
Por fim, quando se detalha as proporções da pilastra principal toscana, conferimos a erudição técnica de José Fernandes Pinto Alpoim, ao projetar seu conjunto de três partes (base, fuste, capitel) com sete módulos e meio seguindo Scamozzi (A) ${ }^{56}$; a altura do entablamento segue, por sua vez, as indicações consensuais entre Scamozzi e Vignola, de um total que corresponda a um quarto da altura total da pilastra (B) ${ }^{57}$. [Figura 21]

Aos olhos dos construtores de Vila Rica, naqueles anos de 1740, o Pórtico do Palácio dos Governadores materializava, com os seus belos detalhes executados na pedra, as principais e corretas modenaturas do repertório compositivo da Tradição Clássica, talvez já esquecidos pelo barroco joanino na capital do reino, mas um repertório ainda vigoroso, exemplar!

As modenaturas desenhadas por Alpoim, e executadas por Caetano o Ruivo seguem os "minutos", 28 submúltiplos do módulo (Q) nas relações verticais (R e T). [Figura 22]

O manifesto dessa cantaria irá repercutir nas elevações das novas edificações de Vila Rica na segunda metade do século XVIII, uma forte característica de apreensão das discretas mas lúcidas lições do sargento-mor Alpoim pela nova geração de oficiais e mestres ${ }^{58}$, e, mesmo que o rigor clássico, retilíneo, maneirista do autor do Palácio dos Governadores não esteja mais em voga até meados do século XIX, a sua contribuição certamente foi inspiradora para uma qualidade da manufatura lítica sempre elevada, expressiva, latente em valores formais na cidade do precioso ouro preto.

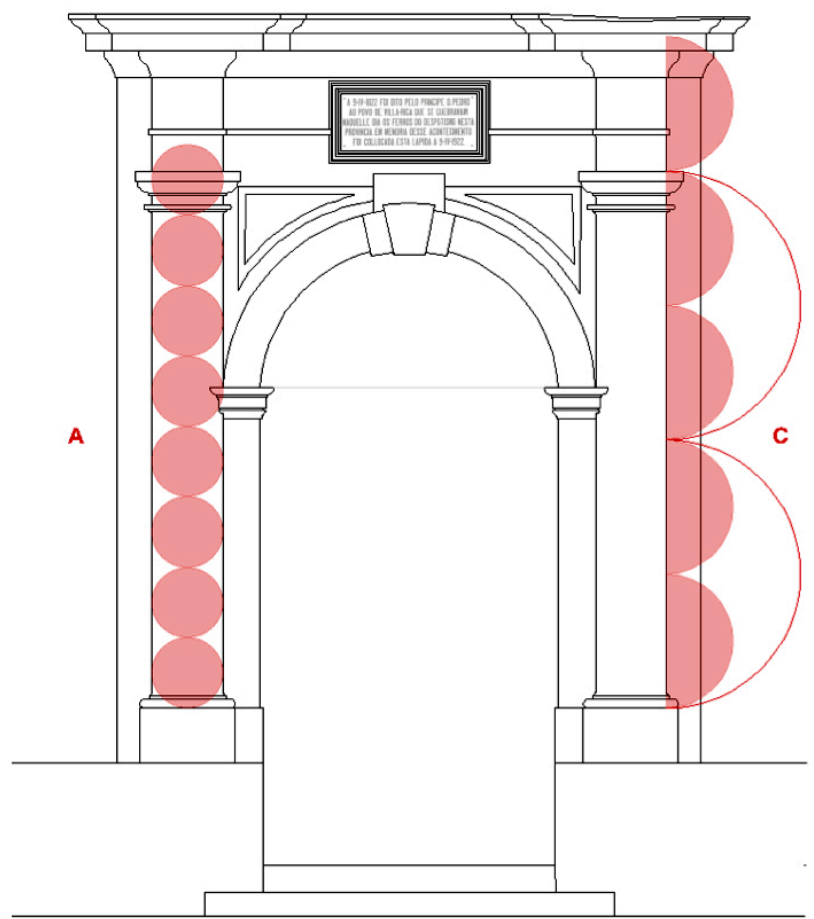


Figura 22: Ouro Preto, Escola de Minas - antigo Palácio dos Governadores, Pórtico de Entrada, modenaturas:
A - Filete de terminação
B - Gola invertida
C - Coroa
D - Gola invertida
E - Friso
F - Filete
G - Caveto
$\mathrm{H}$ - Friso
I - Ábaco
$\mathrm{J}$ - Equino
K - Friso do capitel toscano
L - Astrágalo
$\mathrm{M} / \mathrm{N}$ - Fuste
O - Toro
P - Pedestal.

Fonte: Marcos Tognon, 2018.
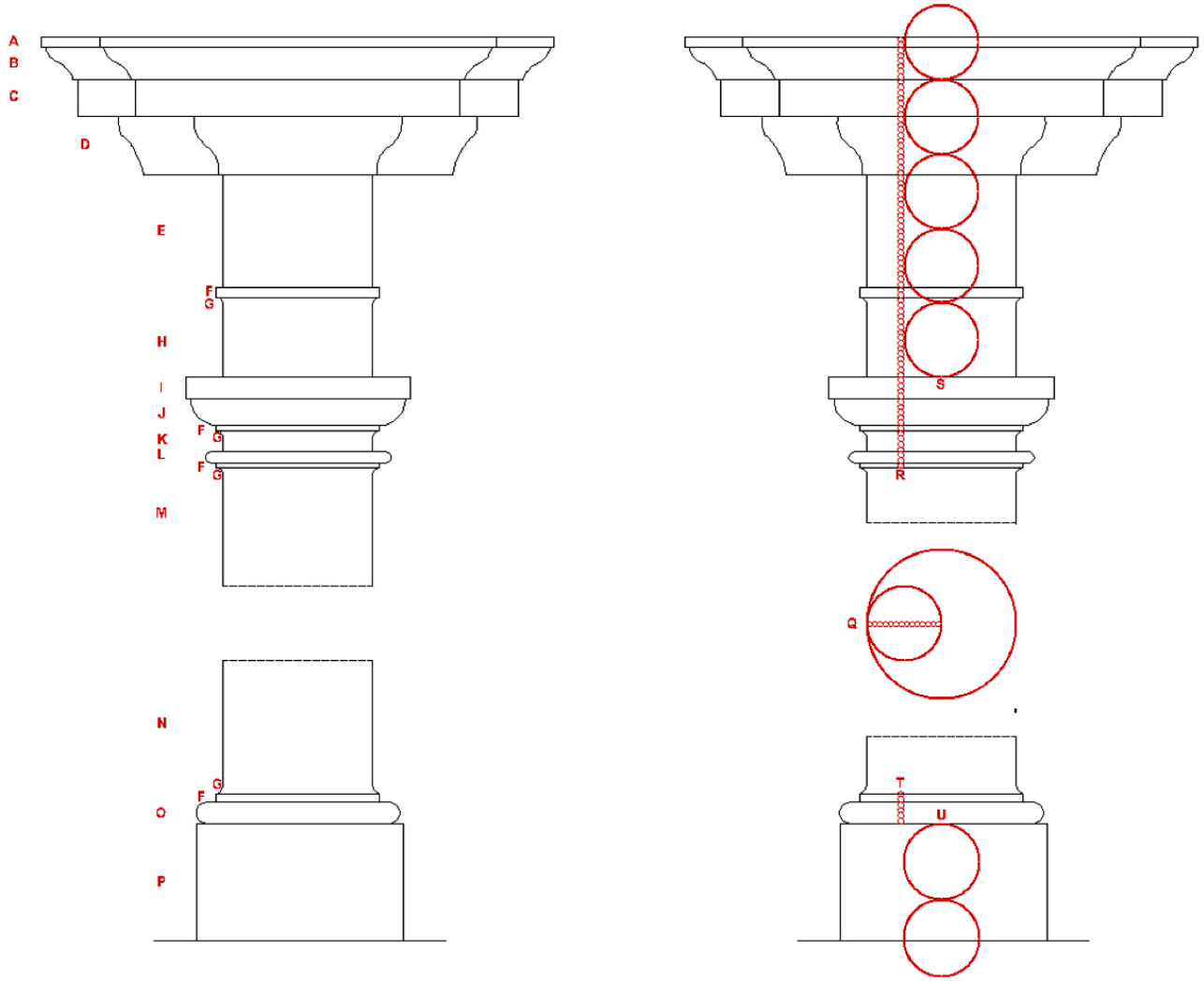

\section{Referências bibliográficas}

ALPOYM, J. [Apontamentos de 13 de junho de 1741]. Revista do Arquivo Público Mineiro, Belo Horizonte, v.6, n.2, p. 574-578, abr.-jun.1901, p.575.

AMATI, Wladimir Mendes. A contribuição de José Fernandes Pinto Alpoim no ensino das técnicas aplicadas à geometria e à ciência no Exame de Bombeiros. 2010. Dissertação (Mestrado em História das Ciências). Centro Simão Mathias de Estudos em História da Ciência, Pontifícia Universidade Católica de São Paulo. São Paulo, 2010.

ANASTASIA, Carla Maria Junho. Guerras, sedições e motins. In: RESENDE, Maria Eugênica L. de; VILLALTA, Luiz Carlos. História de Minas Gerais: as Minas setecentista. Belo Horizonte, Autêntica: Companhia do Tempo, 2007, v.1.

BASTOS, Rodrigo. A arte do urbanismo conveniente: decoro na implantação de novas povoações em Minas Gerais na primeira metade do século XVIII. Florianópolis, UFSC, 2014.

BERNARDO, Luís M.A.V. O projecto intelectual de Manuel de Azevedo Fortes. Lisboa, Imprensa Nacional/Casa da Moeda, 2005.

BRETAS, Rodrigo José Ferreira. Traços biográficos relativos ao finado Antônio Francisco Lisboa distinto escultor mineiro, mais conhecido pelo apelido de Aleijadinho [1858]. Belo Horizonte, UFMG, 2013.

BUENO, Beatriz P. Siqueira. Desenho e desígnio: o Brasil dos engenheiros militares (1500-1822). São Paulo, Edusp, 2011.

"Desenhar" (Projetar) em Portugal e Brasil nos séculos XVI - XVIII. São Paulo, LAP-FAU-USP, 2002. 
CAMILO, Janaína. Homens e pedras no desenho das fronteiras: a construção da Fortaleza de São José de Macapá (1762-1782). Brasília, Ed. Senado federal, 2009.

CARVALHO, José Murilo de. A Escola de Minas de Ouro Preto: o peso da glória. 2.ed.rev. Belo Horizonte, Editora da UFMG, 2002.

CAVALCANTI, Irenilda R.B.R.M. O Comissário real Martinho de Mendonça: práticas administrativas na primeira metade do século XVIII. 2010. Tese (Doutorado em História Social). Instituto de Ciências Humanas e Filosofia, Universidade Federal Fluminense, Niterói, 2010.

CAVALCANTI, Lauro (org.). Paço Imperial. Rio de Janeiro, Index, 2005.

CAVALCANTI, Nireu. O Rio de Janeiro Setecentista. Rio de Janeiro, Zahar, 2004.

CONSTRUCÇÃo do palácio de governo em Ouro Preto. Revista do Arquivo Público Mineiro, Belo Horizonte, v. 6, p. 569-591, 1901.

COSTA, Antonio Gilberto. Mapa das pedras do patrimônio de Minas, dossiê da Revista do Arquivo Público Mineiro, n. 27, s.d., p. 36-38.

Os documentos cartográficos e outras iconografias: importância na pesquisa e na preservação do patrimônio cultural brasileiro. In: Simpósio Brasileiro de Cartografia Histórica, 1.2011, Paraty, RJ. Anais. Paraty, UFMG, 2011.

Rochas e Histórias do Patrimônio Cultural do Brasil e de Minas. Rio de Janeiro, Bem-te-vi, 2009.

DANGELO, André Guilherme Dornelles. A cultura arquitetônica em Minas Gerais e seus antecedentes em Portugal e na Europa: arquitetos, mestres de obras e construtores e o trânsito de cultura na produção da arquitetura religiosa em Minas Gerais setecentistas. 2006, 4 v. Tese (Doutorado em História). Faculdade de Filosofia e Ciências Humanas, Universidade Federal de Minas Gerais, Belo Horizonte, v. 2, 2006.

DIAS, Pedro. História da Arte luso-Brasileira: urbanização e fortificação. Coimbra, Almedina, 2004.

DOCUMENTOS. Revista do Arquivo Público Mineiro. Belo Horizonte, v. 16, n. 2., jul.-dez. 1911, p. 236-460.

FONSECA, Cláudia Damasceno. Arraiais e vilas d'El Rei. Belo Horizonte, Ed. UFMG, 2011.

FORTES, Manoel Azevedo. O Engenheiro Portuguez: dividido em dous tratados. Lisboa, Officina de Manoel Fernandes da Costa, Impressor do Santo Officio, 1729.

LOPES, Francisco Antonio. Os palácios de Vila Rica: Ouro Preto no ciclo do ouro. Belo Horizonte, Imprensa Oficial, 1955.

MACHADO, Simão Ferreira. Thriunfo Eucharistico: exemplar da Christandade Luzitana em pública exaltação da fé na solemne tansladação do Diviníssimo Sacramento da Igreja da Senhora do Rosário para um novo templo da Senhora do Pilar em Villa Rica [Lisboa Occidental: Na officina da música, 1734]. In: Revista do Arquivo Público Mineiro. Belo Horizonte, v. 6, n. 2, p. 985-1016. abr.-jun. 1901.

MATTOS, Anibal. Monumentos Históricos, Artísticos e Religiosos de Minas Geraes. Belo Horizonte, Apollo, 1935.

MELLO, Suzy de. Barroco Mineiro. São Paulo, Brasiliense, 1985, p. 192.

MENESES, Ivo Porto de. Os palácios dos governadores em Ouro Preto. Cadernos de Arquitetura e Urbanismo, Belo Horizonte, v. 12, n. 13, p. 39-58, dez. 2005.

MENESES, José Newton Coelho. O continente rústico. Diamantina (MG), Maria Fumaça Ed., 2000.

MENEZES, J.; RODRIGUES, M. Fortificações portuguesas no nordeste do Brasil: Séculos XVI, XVII e XVIII. Recife, Pool, 1986. 
MIRANDA, Marcos Paulo de Souza. O Aleijadinho revelado. Belo Horizonte, Fino Traço, 2014.

MONTEIRO, John Manuel. Os caminhos da memória: paulistas no Códice Costa Matoso. Varia História, Belo Horizonte, n. 21, p. 86-99, jul. 1999, p. 95.

MOREAU, Filipe Eduardo. Arquitetura militar em Salvador da Bahia: séculos XVI - XVIII. São Paulo, Intermeios, 2016.

MORI, Vitor Hugo. Arquitetura militar: um panorama histórico a partir do Porto de Santos. São Paulo, Fund. Cultural Exército Brasileiro, 2003.

MOROLLI, Gabriele. « Vetus Etruria»: il mito degli etruschi nella leterratura architettonica nell'arte e nella cultura da Vitruvio a Winckelmann. Florença, Alinea, 1985.

MOTA, Catarina; RALHA, Maria Elfrida; ESTRADA, Maria Fernanda. Engenheiros portugueses no século XVIII: as suas "geometrias especulativas". In: Congresso SEHCYT, 12. 2015, Madrid. Anais. Madrid: Sociedad Española de Historia de las Ciencias y de las Técnicas, 2015. p. 163-170.

OLIVEIRA, Mário Mendonça de. As fortificações portuguesas de Salvador quando Cabeça do Brasil. Salvador, Fund. Gregório de Mattos, 2004.

PIMENTEL, Luis Serrão. Methodo Lusitanico de desenhar as fortificações das Praças regulares e irregulares, fortes de campanha, e outras obras pertencentes a architectura militar distribuido em duas partes operativa, e qualificativa. Lisboa, Antonio Craesbeeck de Melo Impressor de S. Alteza, 1680.

PIVA, Teresa Cristina de Carvalho. O Brigadeiro Alpoim: um expoente do ensino técnico no Brasil Colonial. História da Ciência e Ensino, São Paulo, v. 12 esp., p. 54-69, 2015, p. 55; ver também outra listagem em FERREIRA-ALVES, Natália Marinho (coord.). Dicionário de Artistas e Artífices do Norte de Portugal. Porto, CEPESE, 2008, p. 14-15.

O Brigadeiro Alpoim: um politécnico no cenário luso-brasileiro do século XVIII. 2007. Tese (Doutorado em História das Ciências, das Técnicas e Epistemologia). Universidade Federal do Rio de Janeiro, Rio de Janeiro, 2007.

PIVA, Teresa Cristina de Carvalho; COSTA, Nelson Lage da. Uma breve história do Convento dos Barbonos. In: CONGRESSO DE HISTÓRIA DAS CIÊNCIAS DAS TÉCNICAS E EPISTEMOLOGIA, 5., 2012, Rio de Janeiro. Anais. Rio de Janeiro: Programa de Pós-Graduação em História das Ciências, das Técnicas e Epistemologia (HCTE), 2012.

PORTUGAL. Comissão Nacional para as Comemorações dos Descobrimentos Portugueses. A arquitectura militar na expansão portuguesa. Porto, Infante 94, 1994.

REIS, Nestor Goulart. Imagens de vilas e cidades do Brasil Colonial. São Paulo, Ed. USP, 2000, p. 216.

REMATAÇÃO DO PORTICO dO PALACIO [...] Revista do Arquivo Público Mineiro. Belo Horizonte, v,6, n.1. , 1901, p.579.

REVISTA PROJETO. São Paulo, n. 20, 1984, p. 135-157.

RIBEIRO, Dulcyene Maria. A formação dos engenheiros militares: Azevedo Fortes, Matemática e ensino de Engenharia militar no século XVIII em Portugal e no Brasil. 2009. Tese (Doutorado em Educação). Faculdade de Educação, Universidade de São Paulo. São Paulo, 2009.

RODRIGUES, José Wasth. Documentário Arquitetônico. São Paulo, Livraria Martins, 1944, 7 volumes.

RUSSEL-WOOD, A.J.R. Manuel Francisco Lisboa. Belo Horizonte, Escola de Arquitetura da UFMG, 1968.

SALES, Fritz Teixeira de. Vila Rica do Pilar. Belo Horizonte, Itatiaia, 1999. 
SANTOS, João Henrique. Do terreiro do paço à praça XV: a análise da tipologia de um centro de poder no Rio de Janeiro. In: Colóquio Ibero-Americano da Paisagem Cultural, Patrimônio e Projeto, 3. 2014, Belo Horizonte. Anais. Belo Horizonte, Universidade Federal de Minas Gerais, 2015.

SCAMOZZI, Vincenzo. L'Idea della Architettura Universale. Veneza, G. Valentino, 1615.

SERLIO, Sebastiano. Regole generali di Architettura sopra le cinque maniere degli edifici: cioe, thoscano, dorico, ionico, corinthio, et composito, con gli essempi dell'antiquita, che, per la magior parte concordano con la dottrina di Vitruvio. Venetia, Francesco Marcolini da Forli, 1537.

SEVERINI, Giancarlo. Progetto e disegno nei trattati di architettura militare del Cinquecento. Pisa, Pancini, 1994.

TEIXEIRA, André. Fortalezas do Estado Português da Índia. Lisboa, Tribuna da História, 2008.

TONERA, Roberto; OLIVEIRA, Mário Mendonça de. As defesas da ilha de Santa Catarina e do Rio Grande de São Pedro em 1786. Florianópolis, Ed. UFSC, 2015.

VÁRIOS. A Escola de Minas : cum mente et malleo, centenário da indepedencia. Ouro Preto, Mineira, [1922].

VASCONCELLOS, Sylvio. Vila Rica. Rio de Janeiro, INL/MEC, 1956.

VAUBAN, Sébastien le Preste du. Véritable manière de bien fortifier de Mr. de Vauban: Où I'on voit de quelle methode on se sert aujourd'hui en France, pour la fortification des place. Amsterdam, Pierre Mortier, 1703.

VELLOZZO, Diogo Sylveyra. Arquitetura militar ou fortificação moderna. Salvador, EDUFBA, 2005.

VIGNOLA, Jacomo Barozzio da. Regola delli cinque ordini d'Architettura. Roma, [s.n.], 1562.

Regras das sinco ordens de Architectura segundo os princípios de Vignhola, Com hum Ensaio sobre as mesmas ordens feito sobre o sentimento dos mais celebres Architectos. Coimbra, Real Imprensa da Universidade, 1787.

\section{Notas}

1 Essa comunicação tem como ponto de partida os estudos realizados para a nossa tese de livre docência apresentada no Departamento de História do Instituto de Filosofia e Ciências Humanas da UNICAMP em março de 2019; sobre o uso das rochas no patrimônio edificado de Ouro Preto ver COSTA, Antonio Gilberto. Mapa das pedras do patrimônio de Minas, dossiê da Revista do Arquivo Público Mineiro, n. 27, s.d., p. $36-38$.

2 LOPES, Francisco Antonio. Os palácios de Vila Rica: Ouro Preto no ciclo do ouro. Belo Horizonte: Imprensa Oficial, 1955; MENESES, Ivo Porto de. Os palácios dos governadores em Ouro Preto. Cadernos de Arquitetura e Urbanismo, Belo Horizonte, v. 12, n. 13, p. 39-58, dez. 2005; generalidades são comuns em alguns registros historiográficos como Mello "Entretanto, a grande residência oficial que se destaca nas Minas [...] é a Casa dos Governadores, na praça que ocupa o alto do morro de Santa Quitéria, na antiga Vila Rica. Sua pesada volumetria, resolvida à feição de fortaleza, representava bem a opressão portuguesa e, até hoje, é um símbolo claro do despotismo que caracterizou o poder colonizador naquele período". MELLO, Suzy de. Barroco Mineiro. São Paulo: Brasiliense, 1985, p. 192.

3 Documentos dos atos do Governo da capitania de Minas Gerais publicados em CONSTRUCÇÃO do palácio de governo em Ouro Preto, Revista do Arquivo Público Mineiro, Belo Horizonte, v. 6, p. 569-591, 1901.

4 LOPES, op. cit., p. 34.

5 MENESES, op. cit., p. 42.

6 Idem, p. 44. 
7 Ver relato do vereador Joaquim José da Silva [1790] transcrito por BRETAS, Rodrigo José Ferreira. Traços biográficos relativos ao finado Antônio Francisco Lisboa distinto escultor mineiro, mais conhecido pelo apelido de Aleijadinho [1858]. Belo Horizonte: UFMG, 2013, p. 47-49; RUSSEL-WOOD, A.J.R. Manuel Francisco Lisboa. Belo Horizonte, Escola de Arquitetura da UFMG, 1968, p. 25 et seq.; SALES, Fritz Teixeira de, Vila Rica do Pilar. Belo Horizonte: Itatiaia, 1999, p. 100-101; DANGELO, André Guilherme Dornelles. A cultura arquitetônica em Minas Gerais e seus antecedentes em Portugal e na Europa: arquitetos, mestres de obras e construtores e o trânsito de cultura na produção da arquitetura religiosa em Minas Gerais setecentistas. 2006, 4 v. Tese (Doutorado em História). Faculdade de Filosofia e Ciências Humanas, Universidade Federal de Minas Gerais, Belo Horizonte. v. 2, p. 307; MIRANDA, Marcos Paulo de Souza. O Aleijadinho revelado. Belo Horizonte: Fino Traço, 2014, p. 29-39.

8 Ver VASCONCELLOS, Sylvio. O meio físico . In: Vila Rica. Rio de Janeiro: INL/MEC, 1956, cap. 3, p. 50-70; ver também a original interpretação desta vila tentacular por BASTOS, Rodrigo. A arte do urbanismo conveniente: decoro na implantação de novas povoações em Minas Gerais na primeira metade do século XVIII. Florianópolis, UFSC, 2014; outro registro que nos apoia em tal tese seria de Mello "Tratava-se então de construir em pedra e cal uma verdadeira fortaleza, inclusive com baluartes, e para a qual já se tinha armamento. [...] Dentro desse partido, que incluía os principais elementos das fortalezas, Alpoim efetivamente aproveitou as condições do terreno e, de forma exemplar, deu à praça principal de Vila Rica um monumento à autoridade da Coroa Portuguesa." MELLO, op. cit., p. 194.

${ }^{9}$ CONSTRUCÇÃO... op. cit. p. 572 et seq.

10 MACHADO, Simão Ferreira. Thriunfo Eucharistico: exemplar da Christandade Luzitana em pública exaltação da fé na solemne tansladação do Diviníssimo Sacramento da Igreja da Senhora do Rosário para um novo templo da Senhora do Pilar em Villa Rica [Lisboa Occidental: Na officina da música, 1734] Revista do Arquivo Público Mineiro, Belo Horizonte, v. 6, n. 2, p. 985-1016. abr.-jun. 1901, p. 994.

${ }^{11}$ Decreto do rei $D$. João $V$ ordenando o estabelecimento de aulas teóricas de Artilharia e de uso de fogos artificiais no novo Terço de Artilheiros criado no Rio de Janeiro, nomeando para mestre o sargento-mor José Fernandes Pinto Alpoim: "Fui servido haver por bem por decreto de treze deste presente mês e ano que se estabeleça a dita Aula e para mestre dela nomeei a José Fernandes Pinto Alpoim, que proximamente provi no Posto de Sargento-Mor do referido Terço, o qual além dos exercícios a que é obrigado pelo mesmo Posto o será a ditar postila e ensinar a teoria da artilharia a todos que quiserem aplicar-se a ela e especialmente aos oficiais do dito Terço, nesta primeira criação forem providos, os quais serão igualmente obrigados a assistir as Lições da Aula ao menos por tempo de cinco anos e faltando a ela serão castigados a vosso arbítrio", apud AMATI, Wladimir Mendes. A contribuição de José Fernandes Pinto Alpoim no ensino das técnicas aplicadas à geometria e à ciência no Exame de Bombeiros. 2010. Dissertação (Mestrado em História das Ciências). Centro Simão Mathias de Estudos em História da Ciência, Pontifícia Universidade Católica de São Paulo. São Paulo. p 11.

12 Ver PIVA, Teresa Cristina de Carvalho. O Brigadeiro Alpoim: um politécnico no cenário luso-brasileiro do século XVIII. 2007. Tese (Doutorado em História das Ciências, das Técnicas e Epistemologia). Universidade Federal do Rio de Janeiro, Rio de Janeiro.

13 "São edificações de Alpoim no Rio de Janeiro: o Paço Imperial, o Convento dos Barbonos (demolido), a I greja Nossa Senhora da Conceição e Boa Morte, Casa de Câmara e dadeira no Rio de Janeiro, o arruamento do Largo de São Francisco, O Convento da Ajuda (demolido), a reforma do Claustro do Mosteiro de São Bento, a casa dos Telles de Meneses e o Arco dos Telles, a Quinta do Bispo, antiga residência episcopal no Rio Comprido, a Igreja e o Convento de Santa Teresa, a reconstrução do Aqueduto da Carioca, a reforma da Fachada da Igreja de Nossa Senhora do Bonsucesso, a Igreja de nossa Senhora Mãe dos Homens, a sede da Fazenda Jurujuba e a antiga Casa do trem de Artilharia. Em Minas Gerais são suas obras: o traçado da cidade de Mariana, O Palácio dos Governadores em Vila Rica (atual cidade de Ouro Preto) [...] a Casa de Câmara e Cadeira em Vila Rica, e o casario assobradado próximo ao Antigo Palácio dos Governadores" PIVA, Teresa Cristina de Carvalho. O Brigadeiro Alpoim: um expoente do ensino técnico no Brasil Colonial. História da Ciência e Ensino, São Paulo, v. 12 esp., p. 54-69, 2015, p. 55; ver também outra listagem em FERREIRA-ALVES, Natália Marinho (coord.). Dicionário de Artistas e Artífices do Norte de Portugal. Porto: CEPESE, 2008, p. 14-15.

14PIVA, 2007, op.cit.; RIBEIRO, Dulcyene Maria. A formação dos engenheiros militares: Azevedo Fortes, Matemática e ensino de Engenharia militar no século XVIII em Portugal e no Brasil. 2009. Tese (Doutorado em Educação). Faculdade de Educação, Universidade de São Paulo. São Paulo. p. 179-183; MOTA, Catarina; RALHA, Maria Elfrida; ESTRADA, Maria Fernanda. Engenheiros portugueses no século XVIII: as suas "geometrias especulativas". In: CONGRESSO SEHCYT, 12. 2015, Madrid. Anais. Madrid: Sociedad Española de Historia de las Ciencias y de las Técnicas,2015. p. 163-170.

15 AMATI, op. cit., p. 11.

16 MOTA, op. cit., p. 166. 
17 Ver Manoel Azevedo Fortes, "Representação feita a S. Majestade que Deus guarde [...] sob a forma e direção, que devem ter os Engenheiros para melhor servirem ao dito Senhor neste Reino, e suas Conquistas", In: BERNARDO, Luís M.A.V., O projecto intelectual de Manuel de Azevedo Fortes. Lisboa: Imprensa Nacional/Casa da Moeda, 2005, p. 231, 234-235.

18SANTOS, João Henrique. Do terreiro do paço à praça XV: a análise da tipologia de um centro de poder no Rio de Janeiro. In: Colóquio Ibero-Americano da Paisagem Cultural, Patrimônio e Projeto, 3. 2014, Belo Horizonte. Anais. Belo Horizonte: Universidade Federal de Minas Gerais, 2015. p.n.n. [CD-ROM]; ver também CAVALCANTI, Nireu. O Rio de Janeiro Setecentista. Rio de Janeiro: Zahar, 2004.

19 Ver Revista Projeto, São Paulo, n. 20, 1984, p. 135-157; CAVALCANTI, Lauro (org.). Paço Imperial. Rio de Janeiro: Index, 2005.

20PIVA, Teresa Cristina de Carvalho; COSTA, Nelson Lage da. Uma breve história do Convento dos Barbonos. In: Congresso de História das Ciências das Técnicas e Epistemologia, 5., 2012, Rio de Janeiro. Anais. Rio de Janeiro: Programa de Pós-Graduação em História das Ciências, das Técnicas e Epistemologia (HCTE), 2012. p.n.n. Disponível em <http://www.hcte.ufrj.br/downloads/sh/sh5/trabalhos\%20orais\%20completos/ trabalho_107.pdf>. Acessado em 01.out.2018.

21 "Chamado outrora Palácio 'Novo', pois primitivamente, os Governadores moravam em Mariana e, quando iam a Ouro Preto, ocupavam, uma casa que existiu no bairro de Antônio Dias; é hoje a escola de Minas. Foi construída por ordem de Gomes Freire de Andrade sob traçado do engenheiro sargento-mor José Fernandes Pinto de Alpoim. A sua construção foi arrematada em hasta pública por Manuel Francisco Lisboa, pai de Antônio Francisco Lisboa, o 'Aleijadinho'. Sólida construção assobradada com cunhais e vãos em cantaria do Itacolomi, num terreno em declive e dominante, formando na frente terraço e rampa de acesso reforçados por sólidos paredões em talude, e tendo, nos quatro ângulos, baluartes com guaritas, cordão e parapeito: mais duas guaritas guarnecem o terraço. Serviu também de residência aos Presidentes da Província e do Estado até 1898, quando o governo se passou para a nova capital: Belo Horizonte. Tinha internamente calabouços, saguão e outros complementos militares." ESTAMPA 12 [legenda]. Ouro Preto: Antigo Palácio dos Governadores. In: RODRIGUES, José Wasth. Documentário Arquitetônico. São Paulo: Livraria Martins, 1944, é nessa estampa que Wasth Rodrigues propõe uma reconstrução do "Aspecto Antigo", com os baluartes não ocupados, e com a presença das rampas de acesso, configuração que, pela documentação, não encontra coerência, pois os baluartes já estariam ocupados antes de 1781, ver LOPES, op. cit., p. 31: "A capela do Palácio, ocupando um dos baluartes na frente, foi construída em época anterior a 1781. É desse ano um mandato de pagamento a Manuel Francisco de Araújo (nota 51), de perto de um conto e trezentos mil reis, 'importância do Retábulo da Capela deste Palácio' "; as ilustrações 20 (prancha XVII) e 22 (prancha XVIII) de nossa tese já tinham sido publicadas em 1935, veja MATTOS, Anibal. Monumentos Históricos, Artísticos e Religiosos de Minas Geraes. Belo Horizonte: Apollo, 1935, p. 306-307.

22 "Portal em estilo toscano, amplo e de desenho simples e elegante, no gênero dos portais das casas fortes e fortalezas. Sua cornija, que sustenta a janela, se apoia sobre o cordão da muralha. Na janela destancam-se o caixilho sóbrio e moderno para a época, e a sacada de ferro à moda portuguesa. Seu desenho é do autor do Palácio, o sargento-mor José Fernandes Pinto de Alpoim, e sua execução foi arrematada em 1742 por Caetano Silva, o Ruivo, informa o Guia de Ouro Preto." RODRIGUES, op. cit., ESTAMPA 16. Ouro Preto. Portal do Palácio dos Governadores.

23 Ver DIAS, Pedro. História da Arte luso-Brasileira: urbanização e fortificação. Coimbra: Almedina, 2004, p. 276-277.

24 "[...] um conjunto de bandidos de todas as nações, que pouco a pouco formaram uma grande cidade e uma espécie de República, onde eles têm como lei não reconhecer o governador de forma alguma [...]" In: MONTEIRO, John Manuel. Os caminhos da memória: paulistas no Códice Costa Matoso. Varia História, Belo Horizonte, n. 21, p. 86-99, jul. 1999, p. 95.

25Ver a excelente antologia de textos organizada por ANASTASIA, Carla Maria Junho. Guerras, sedições e motins. In: RESENDE, Maria Eugênica L. de; VILLALTA, Luiz Carlos História de Minas Gerais: as Minas setecentista. Belo Horizonte: Autêntica: Companhia do Tempo, 2007, v.1, p. 525-584.

${ }^{26}$ ANASTASIA, Carla Maria Junho. Um exercício de auto-subversão: rebeldes fascinorosos na Sedição de 1736. In RESENDE, M. E. L. de; VILLALTA, L. C., op. cit., p. 568; ver as cartas de Gomes Freire de Andrada, Conde de Bobadela e Martinho de Mendonça de Pina e Proença, Governador Interino Administração Colonial Portuguesa pulicadas em: DOCUMENTOS. Revista do Arquivo Público Mineiro, Belo Horizonte, v. 16, n. 2., p. 236-460, jul.-dez. 1911.

27Ver CAVALCANTI, Irenilda R.B.R.M. O Comissário real Martinho de Mendonça: práticas administrativas na primeira metade do século XVIII. 2010. Tese (Doutorado em História Social). Instituto de Ciências Humanas e Filosofia, Universidade Federal Fluminense, Niterói. 
28FONSECA, Alexandre Torre. A Revolta de Felipe dos Santos. In: RESENDE, Maria Eugênica L. de; VILLALTA, Luiz Carlos, op. cit., p. 560-564.

29 Para uma avaliação plural do problema da alimentação no Serro Frio mineiro ver MENESES, José Newton Coelho. O continente rústico. Diamantina (MG): Maria Fumaça Ed., 2000.

30 Cf. VASCONCELLOS, op. cit., p. 114; para os movimentos promovidos de urbanização difusa por toda a capitania ver FONSECA, Cláudia Damasceno. Arraiais e vilas d'El Rei. Belo Horizonte: Ed. UFMG, 2011.

31 "Tendo feito subir As Minas o sargento-mor engenheiro José Fernandes Pinto Alpoim, incumbe-o Gomes Freire de organizar o projeto e os 'Apontamentos para a obra q[eu] se pretende fazer por conta da Real Fazenda em V[il]a rica na casa forte'. Ao ler esses apontamentos [...] de junho de 1741, e que são detalhadas as condições, alongando-se por grande número de cláusulas, verifica-se que, apesar de se referirem ao aproveitamento de partes das antigas edificações, já visavam a construção inteiramente nova. E o edifício que nos veio dos tempos coloniais mostra bem, em seus detalhes arquitetônicos, ter sido feito sem a utilização de obras já existentes", In LOPES. op. cit., p. 17.

32 Ver o ótimo panorama oferecido por DIAS, Pedro, O desenvolvimento da fortificação regular. In: op. cit., cap.2, p. 57-103; ainda sobre as praças fortificadas regulares no Brasil ver MORI, Vitor Hugo. Arquitetura militar: um panorama histórico a partir do Porto de Santos. São Paulo: Fund. Cultural Exército Brasileiro, 2003; OLIVEIRA, Mário Mendonça de. As fortificações portuguesas de Salvador quando Cabeça do Brasil. Salvador: Fund. Gregório de Mattos, 2004; CAMILO, Janaína. Homens e pedras no desenho das fronteiras: a construção da Fortaleza de São José de Macapá (1762-1782). Brasília: Ed. Senado federal, 2009; TONERA, Roberto; OLIVEIRA, Mário Mendonça de. As defesas da ilha de Santa Catarina e do Rio Grande de São Pedro em 1786. Florianópolis: Ed. UFSC, 2015; MOREAU, Filipe Eduardo. Arquitetura militar em Salvador da Bahia: séculos XVI - XVIII. São Paulo: Intermeios, 2016; ainda no âmbito colonial português dos empreendimentos em fortificações ver TEIXEIRA, André. Fortalezas do Estado Português da India. Lisboa: Tribuna da História, 2008; sobre o ensino e as práticas de projeto no âmbito luso-brasileiro ver BUENO, Beatriz P. Siqueira. "Desenhar" (Projetar) em Portugal e Brasil nos séculos XVI - XVIII. São Paulo: LAP-FAU-USP, 2002.

${ }^{33} \mathrm{Cf}$. SEVERINI, Giancarlo. Progetto e disegno nei trattati di architettura militare del Cinquecento. Pisa: Pancini, 1994. p. 50-51: "Per i trattatisti del '500, architetti e ingegneri, a differenza di quelli del secolo precedente che attingevano dalla tradizone e dalla pratica, è próprio l'attività di fortificare, nella quale confluiscono scienze e tecniche varie e complesse, che richiede di essere sottoposta a formulazioni teoriche - dotate di un próprio lessico, inteso come definizione preliminare dei termini impiegati e quindi di un linguaggio tecnicamente corrispondente - secondo le quali fra le parti che compongono le difese vengono individuati rapporti costanti e regolari, la trasformazione di una riflettendosi sulle altre. II disegno dele nuove fortificazioni può quindi essere 'ottimizzato' per mezzo dela matemática e di relazioni numeriche e logiche, che collegano le forme ala geometria e alle traiettorie dei tiri."

${ }^{34} \mathrm{~A}$ publicação foi organizada e promovida pelo nosso querido mestre Professor Mário Mendonça de Oliveira In VELLOZZO, Diogo Sylveyra. Arquitetura militar ou fortificação moderna. Salvador: EDUFBA, 2005.

35 LOPES, op. cit., p. 31.

36 Ver VAUBAN, Sébastien le Preste du. Véritable manière de bien fortifier de Mr. de Vauban: Où l'on voit de quelle methode on se sert aujourd'hui en France, pour la fortification des place. Amsterdam: Pierre Mortier, 1703, v.3., p. 109-135.

${ }^{37}$ ALPOYM, J. [Apontamentos]13 de junho de 1741. Revista do Arquivo Público Mineiro, Belo Horizonte, v.6, n.2, p. 574-578, abr.-jun.1901. p.575.

38 "Em reunião da Junta da Fazenda [...], no mês de novembro de 1766, é proposto pelo seu presidente, o governador Lobo da Silva, e aprovado pelos deputados, dividir a casa que serve de 'Provedoria com hum Frontal, abrindolhe porta para o Baluarte correspondente à janela contígua, tirar o aterro deste e fazer na aria do mesmo hua Caza dandolhe lus com duas janelas para que fosse útil ao exercício de maior consequência da Contadoria' Por essa obra foi aceito o lanço oferecido pelo mestre Manoel Francisco Lisboa", In LOPES, op. cit., p. 30.

39Ver. A Escola de Minas: cum mente et malleo, centenário da indepedencia. Ouro Preto: Mineira, [1922]; CARVALHO, José Murilo de. A Escola de Minas de Ouro Preto: o peso da glória. 2.ed.rev. Belo Horizonte: Editora da UFMG, 2002.

40 Publicado em REIS, Nestor Goulart. Imagens de vilas e cidades do Brasil Colonial. São Paulo: Ed. USP, 2000, p. 216. 
41 Ver LOPES, Francisco Antônio. Pelourinho. In op. cit., p. 117-123, e, COSTA, Antonio Gilberto. Os documentos cartográficos e outras iconografias: importância na pesquisa e na preservação do patrimônio cultural brasileiro. In SIMPÓSIO BRASILEIRO DE CARTOGRAFIA HISTÓRICA, 1.2011, Paraty, RJ. Anais. Paraty: UFMG, 2011, p. 21-23.

42 "A Capela do Palácio, ocupando um dos baluartes da frente, foi construída em época anterior a 1781. É deste ano um mandado de pagamento a Manoel Francisco de Araújo[...] de perto de um conto e trezentos mil réis, 'importância do retábulo da Capela deste Palácio'. Datará, no entanto, essa construção de época posterior a 1766, que é quando ficou resolvido, como se viu acima, o destêrro do baluarte que a recebeu", In LOPES, op. cit., p. 31.

43 Publicado em REIS, op. cit., p. 215.

44 "Apontamento para as obras q. se pretende fazer por conta da Real Fazenda em V.a Rica na casa forte". ALPOYM, op.cit. p. 574.

45 Programa coordenado pelo Prof. Carlos Alberto Pereira desde 2005, Departamento de Mineralogia da Escola de Minas, UFOP.

46 "Anno de Nacim.to de de Nosso Senhor Jesus Christo de mil settecentos e quarenta e hum ao prim.o de Julho do d.o anno nesta V.a Rica do Ouro preto, em caza da Intendencia da Real Fazenda, sendo ahi e Exm.o Gomes Fr.e de Andr.a Gov.r e Cap.m Gen.l, deste Governo com o D.r Prov.or da Real Fazenda Ant.o Roiz Macedo e o Thezoureiro Jose de Alm. Da Machado comigo escrivão da mesma, pelos d.os Exmo Gen.I e Provedor, foi mandado ao Porteyro Dom.os Miz. Rematasse a Caetano da Silva o Ruivo, M.e cantr.o Portico da pedra do Pallacio desta V.a na forma da planta q. se lhe deu, por quatro centos e sincoenta mil r.s posya a pedra no lugar da obra a custa da Real Fazenda, e com sincoenta outavas de ouro a vista, por não haver q.m menos a fizesse havendo andado em praça o tempo da ley e nesta forma se lhe houve por rematado o Portico na referida q.ta de $450 \$ 000$ rs. q.e elle assentou e de que mandarão fazer auto que assinarão" Rematação do Portico do Palacio [...] Revista do Arquivo Público Mineiro, Belo Horizonte, v,6, n.1. , 1901, p.579.

47Ver COSTA, Antonio Gilberto. Rochas e Histórias do Patrimônio Cultural do Brasil e de Minas, Rio de Janeiro: Bem-te-vi, 2009, p. 142: "Seu portal principal, diferenciando-se das demais cantarias [do Palácio], foi construído em calcário dolomítico extraído na Pedreira do Ôjo, situada entre Gambá e Passagem de Mariana"; ver também MATTOS, op. cit., p. 311: Nas peças de cantaria do edifício, como nas outras obras importantes de Ouro Preto, foi empregada a pedra do Itacolomy. No pórtico de entrada foi applicado o 'calcareo do Ojô', das proximidades de Ouro Preto."

${ }^{48}$ Cf. SCAMOZZI, Vincenzo. L'Idea della Architettura Universale. Veneza: G. Valentino, 1615, Parte 2, v.6, cap. 1, p. 3: "E prima il Toscano, essendo cosi nel tutto, come anco nelle sue parti, e membra molto sodo, e robusto; in tanto, che is demostra asai atto a sostenere ogni gravissimo peso; e perciò egli tiene molto del Giganteo."

49 PIMENTEL, Luis Serrão. Methodo Lusitanico de desenhar as fortificações das Praças regulares e irregulares, fortes de campanha, e outras obras pertencentes a architectura militar distribuido em duas partes operativa, e qualificativa. Lisboa: Antonio Craesbeeck de Melo Impressor de S. Alteza, 1680. Parte I, seção I, cap. 35, p. 147.

50FORTES, Manoel Azevedo. O Engenheiro Portuguez: dividido em dous tratados. Lisboa: Officina de Manoel Fernandes da Costa, Impressor do Santo Officio, 1729. v.2., livro VI, cap.5, p. 292.

51 VELOZZO, op.cit. cap. 15, p. 225-226.

52 Ver SERLIO, Sebastiano. Regole generali di Architettura sopra le cinque maniere degli edifici: cioe, thoscano, dorico, ionico, corinthio, et composito, con gli essempi dell'antiquita, che, per la magior parte concordano con la dottrina di Vitruuio. Venetia: Francesco Marcolini da Forli, 1537. Livro IV., p. 5.

53V. VIGNOLA, Jacomo Barozzio da, Regola delli cinque ordini d’Architettura. Roma: [s.n.], 1562, lâm. 4: "Non havendo io fra l'Antichità di Roma trovato ornamento toscanom di che n'habbi possuto formar regola, come ho trovato dell'altri 4 Ordini Dorico lonico Corinto e Composito; ho preso l'autorità di Vitruvio nel quarto libro al settimo capitolo, dove disse la colonna toscana dover essere in alteza di sete grossezze di essa colona con la base e capitello. II resto dell'ornamento cioè architrave, fregio e cornice, mi pare esses convenevole, osservar la regola, la quale ho trovata ne gli altri ordeni cioèm che l'architrave, fregio, et cornice siano la quarta parte dell'altezza dela colonna, la quale e moduli $14 \mathrm{com}$ la base, et capitello, come si vede notato per numeri; così l'architrave, fregio, et cornice saranno moduli $31 \frac{12}{2}$, che viene as essere il quarto di 14. Li suoi particolari membri saranno al luogo suo minutamente notati"; é interessante ver a tradução portuguesa dessa passagem de Vignola, ocorrida somente na segunda metade do século 
XVIII em Coimbra: "A primeira ordem chamada Toscana he a mais robusta,e mais simples porisso propria para os edificios deste carater: as outras vão sendo sucessivamente mais delicadas porisso se empregão, ou sobre as mais robustas isto he, sobre a Toscana, e Dorica, ou para ornar aquella parte do edificio onde forem mais proprias. Como nas antiguidades de Roma se não tem achado algum ornamento toscano pelo qual se podesse estabelecer huma regra para as proporçoens das suas partes como se fez nas outras quatro ordens, Dorica, Jonica, Corinthia e Composita, servimo-nos da autoridade de Vitrubio lib. 4 cap. 7 , onde diz que a coluna toscana com baze, e capitel deve ter de altura 7 das suas grossuras, e que para a architrave, frizo, e cornija se observem as regras estabelecidas para as outras ordens, isto he que estas tres pessas juntas sejaõ a quarta parte da coluna com baze e capitel; e como esta tem 14" como se vê pelos números notados na estampa, segue-se que o architrave, frizo, e cornija juntos devem ser a quarta parte de 14 que vem a ser 3.m 1/2; os membros particulares serão marcados meudamente em figuras maiores, afim de os fazer mais sensiveis". VINHOLA, Regras das sinco ordens de Architectura segundo os princípios de Vihnola, Com hum Ensaio sobre as mesmas ordens feito sobre o sentimento dos mais celebres Architectos. Coimbra: Real Imprensa da Universidade, 1787, p. 61-63.

${ }^{54} \mathrm{Cf}$. MOROLLI, Gabriele. «Vetus Etruria»: il mito degli etruschi nella leterratura architettonica nell'arte e nella cultura da Vitruvio a Winckelmann. Florença: Alinea, 1985, p. 87: "Troppo era, evidentemente, il bisogno di 'regolarizzare', da parte dela mentalità normativa, classificatória tipicamente rinascimentale, la condizione istituzionalmente anomala di questa colona per così dire giunta dall'Antichità stessa senza il crisma, senza il pedigree dell'ordine vero e próprio. Tutti furono, dunque, bem felici di fare próprio il golpe teórico di Serlio e di accettare che il tuscanico fosse um ordine al pari degli altri; ed anzi la consegna fu di attribuire tale opera di fondazione allo stesso Vitruvio. Consegna teorética ala quale tutti furono fedeli salvo, forsem il gran sacerdote dell'ortodossia classicista, Jacopo Barozzi da VIgnola che, pur includendo il tuscanico nelle 'tavole dela legge' dela sua Regola come primo dei cinque ordini, próprio per il su rigorismo per così dire controriformato senti il bisogno, jesuiticamente, di confessar ela totale artificiosità [...]" .

55 Ver MENEZES, J.; RODRIGUES, M. Fortificações portuguesas no nordeste do Brasil: Séculos XVI, XVII e XVIII. Recife: Pool, 1986; PORTUGAL. Comissão Nacional para as Comemorações dos Descobrimentos Portugueses. A arquitectura militar na expansão portuguesa. Porto: Infante 94, 1994. (Catálogo da exposição realizada no Castelo de S. João da Foz, Porto, de Junho a Setembro, 1994).

56 Nessa relação proporcional entre diâmetro da pilastra toscana e sua altura Alpoim segue fielmente Vincenzo Scamozzi, e não Vignola que faz a indicação de sete módulos apenas; ver. SCAMOZZI, op. cit., parte segunda, livro 6, cap. 10, p.32: "E passando più innazi, l'altezza dele minori Colonne, che si convenghino bene di sette moduli, e mezzo: e se pure dagli Architetti moderni ne sono state fatte, e di sei, e di sette Moduli (come dicessimo altrove) non de[v]ono esser lodate, come anco la statura de gli huomini piccioli, e nani; perche in vero non hanno in esse alcuna ragione, nè proportione, o simpatia, con la statura humana [... e perciò rendono gli edifici molto bassi, e depressi [...]" [grifo nosso]; lembramos aqui que a consideração de "módulo" para Scamozzi e, portanto, para Alpoim, é o diâmetro regular no imoscapo dos fustes de colunas ou pilastras, e não o raio desse mesmo fuste como era a compreensão tradicional no século XVI.

57 Cf. SCAMOZZI, op. cit., parte segunda, livro 6, cap. 10, p.32: "La onde il sette, e mezzo viene a esser in proportione al diece, come il terzo, al quarto, e come a dire la sesquialtera paragonata ala proportione duppla. Hor affermati questi due numeri de la maggiore, e minor alteza delle Colonne, sarà assai facil cosa poi a ritrovare le proportioni, \& altezze delle altre. Onde di primo trato habbiamo fato l'ordine Toscano, come robusto, e Giganteo, per no dire Ciclopo: e che le sue Colonne siano com Base, e Capitello di sette Moduli, e mezzo. E l'ornamento; cioè Architrave, e Fregio, e Cornice sopra esse sai alto per il quarto dela loro alteza: e si conta molto bene a questo Ordine"; sobre a mesma proporção do entablamento toscano, de um quarto da altura total da coluna/pilastra, para Giacomo Barozzio da Vignola, ver nota 53 supracitado. 